\title{
Experiences of Capitalism in India and Pakistan
}

\author{
Kalim Siddiqui \\ Senior Lecturer in International Economy \\ University of Huddersfield, UK \\ E-mail: k.u.siddiqui@hud.ac.uk
}

\begin{abstract}
The objective of this study is to examine the economic policies and socio-economic changes which have taken place in South Asia for the last six decades. However, my focus will be mainly on India and Pakistan to try to examine how capitalism has been developing differently in these two countries. It seems to me that this study is important because the proponent of free-market polices (i.e. mainstream economists) ignore the poverty issues and emphasise mainly growth rates and unquestionably assume that 'trickle down' would solve poverty problems. We should also not forget that India is home to the largest number of poor in the world, and as such is an obvious test case for whether pro-market reforms work or not. The ruling elites cite high GDP (gross domestic products) growth rates as indicative of economic development and consequently the well-being of the people.

Growth is seen as a panacea and in order to achieve higher economic growth rates both countries had earlier adopted import-substitution-industrialization (ISI) and later on neo-liberal (i.e. 'free market') economic policies. The study will also analyse the impact of neo-liberal economic reforms on socio-economic situation both in India and Pakistan and its impact on reducing poverty. In Pakistan these reforms were launched in 1988, while in India in 1991 under the IMF supervision. As a result both economies have witnessed an upsurge in GDP growth rates (especially in India). Despite the high GDP growth rates for the last two decades in India, for example, over all employment has not been growing. The service sector, which witnessed a rapid economic growth, accounts for a much smaller share in employment relative to their contribution to GDP. The study finds that capitalism has failed to remove poverty and inequality despite its long history of penetration in South Asia under colonial and neo-colonial regimes and in spite of being backed by the new technology and increased amounts of credits. The experience of Pakistan clearly illustrated this fact. There is a lack of discussion about the presence of a large proportion of people living in sub-human conditions and lack of overall and holistic development of human being.
\end{abstract}

Keywords: India, Pakistan, ISI, Neo-liberal economic Reforms, FDI, Poverty and inequality 


\section{Introduction}

Since independence in 1947, the governments in India and Pakistan have proclaimed a desire to remove poverty through the rapid GDP (gross domestic products) growth rates. In order to achieve higher economic growth rates both countries have earlier adopted import-substitution-industrialisation (ISI) (Note 1) and later on neo-liberal (Note 2) (i.e. 'free market') economic policies. The question arises as to what are the outcomes of these policies in terms of achieving the goals of reducing poverty and inequality in these two south Asian countries.

I find this study is important because the proponent of free-market polices ignore the poverty issues and emphasize mainly their growth rates and unquestionably assume that 'trickle down' would solve poverty problems (Acharya and Mohan, 2010; Ahluwalia, 2002; World Bank, 1997). We should also not forget that India is home to the largest number of poor in the world, and as such is an obvious test case for whether pro-market reforms works or not. The ruling elites cite the high GDP growth rates as indicative of economic development and consequently the well-being of the people. This study relies on the published data to evaluate the macro-economic variables and impact of these policy measures on the people.

There is no doubt that India and Pakistan have a different culture, history and modes of incorporations with the global capitalism and patterns of stratification. The reason for dealing with the two neighbours separately rests on the diagnostic differences in the political and economic situation of each. Pakistan currently has the potential of a "failed state" while in contrast to this, India has the potential to emerge as a major economy in Asia.

The main thrust of this paper is directed at examining economic polices of the last six decades and its impact on the living conditions of the people. The paper also intends to examine sources of variations in growth rates in sectoral and regional terms. The service sector witnessed a rapid expansion compared to manufacturing and agriculture sector during the post-reform period. However, the lack of employment creation in the service sector together with persistent poverty and agriculture crisis mean that unemployment will the biggest problem in coming years. For instance, in India, despite high economic performance, there are still more poor people than in the whole of sub-Saharan Africa - a staggering two million children annually die before their fifth birthday. Moreover, it seems that the South Asian countries will face the existence of large number of poor people as a major challenge in the coming decades of the 21st century. These difficult questions have been overlooked by mainstream economists.

At the time of independence, India inherited a colonial economy. It was largely agrarian and industries were limited to textiles, some steel and chemicals, sugar, and cement (Habib, 1995; Bagchi, 1976). Exports consisted of low value added items like cotton, tea, jute, spices etc. However, prior to colonization of the Indian economy, Britain's imports from India during the first half of the $18^{\text {th }}$ century consisted mainly of textiles, spices and silk. India was the largest exporter of cotton textiles in the world till the end of the $18^{\text {th }}$ century. However, once Britain colonized and subjugated the Indian economy by the middle of $18^{\text {th }}$ century i.e. after the battle of Plassey in 1757 India from being the largest cultivators and producers and exports of 
cotton textiles in the world, when its share of world manufacturing output estimated to be as high as $19.7 \%$ in 1800 , witnessed her share fall sharply to $8.6 \%$ in 1860 and mere $1.4 \%$ in 1913. While at the same time British export of cotton goods to India rose dramatically (Note 3) (Siddiqui, 1990; Bagchi, 1976).

Mukherjee (2010) argues that the colonies played an important role in the development of industries in Britain. He says that the transfer of resources from India to Britain was then vital to its industrialisation. As he notes: "transfer of capital from the colony (India) to the metropolis (UK) in various forms as a "bleeding process" ruinous to the colony but critical to the process of primitive accumulation and therefore to the transition to and growth of industrial capitalism in the metropolitan countries”. (Mukherjee, 2010: 73) Later on he argues that, "Since Britain had nothing to sell to India which she needed therefore the imports from India were financed by export of treasure or bullion i.e. silver and gold got cheap from the rape of Latin America leading to the virtual extinction of the Amerindian (native American) people in many areas” (Mukherjee, 2010:75).

A transformation of this colonial economy could not occur with the spontaneous operation of the market. The state had to take the lead in the production of capital goods industries and the institutional reforms in agriculture enabled the country to increase agricultural production. During the 1950s and 1960s various agrarian legislation were passed but did not succeed in breaking land concentration. While it did encourage large farmers to become capitalist farmers and also the rich tenants acquired ownership rights over land, marginal and landless agricultural workers did not benefit from it. Later on in the mid-1960s with the adoption of the 'Green Revolution', overall agricultural output was increased, which made the country self-sufficient in food grains, but this strategy relied mainly on rich and large farmers to produce more, by passing the small farmers and agricultural labourers (Byres, 1994).

India was a classic case for bourgeoisie economic development and the bourgeoisie was more developed as a class at the time of independence in 1947 than Pakistan. That is to say it had a stronger productive base, owing to greater industrialisation during the British rule and thus was more organized as a class which supported the anti-colonial struggle. It used the state for relatively autonomous capitalist development and asserted itself both politically and economically vs imperial Britain. Immediately after independence India adopted policies to protect domestic markets from foreign goods and capital and at international levels the policy of non-alignment.

In India the Congress Party, which led the anti-imperialist struggle, was an established party and had spelled out clearly the strategy to build an economy on the basis of self-reliance. Its first Prime Minister Jawaharlal Nehru advocated a strong role of the public sector and land reforms to remove rural inequalities (Byres, 1994). There was visible presence of a sizeable national bourgeoisie some of whom even provided funds to the Congress Party. The First Five Year Plan (1951-56) focused on rural development and small and medium enterprises. The Second Five Year Plan (1956-61) was launched to build heavy industries in capital goods sector, which were seen as risky and too expensive for private capital to venture. However, soon the Plan ran into financial difficulties and was looking for Western financial assistance 
and investments. Along with credits came advice and policy recommendations under IMF (International Monetary Fund) guidance to devalue the domestic currency by 58 \% in 1966. The economy was further liberalized to attract foreign capital. During the 1980s India further received aid and credits from the international financial institutions. In 1991, India experienced severe difficulty on its loan payments and at the same time the international monitoring agencies downgraded India's credit ratings. As a result, the commercial banks refused to lend money and the IMF and World Bank were approached for emergency finance. They agreed to provide this on the conditions of introducing Structural Adjustment Programmes (SAP), which is based on neoclassical model of economic development (i.e. free-market policies) (Siddiqui, 2010b).

India's GDP growth rates of 8-9 \% annually in 2009 is claimed to be associated with the adoption of neo-liberal economic reforms. In 2005 it ranked $20^{\text {th }}$ among world exporters, and $15^{\text {th }}$ among the world importers of merchandise. In services, it was the $8^{\text {th }}$ largest exports and $7^{\text {th }}$ largest importers. In 1990 FDI (foreign direct investment) into India were US\$ 165 millions only. After the adoption of neo-liberal economic reforms, the inflows of foreign capital increased dramatically to US\$2,439 million in 1999-2000 and further to \$2,549 million in 2004-05 (The Economist, 2010; Siddiqui, 2010b). However, the rapid increase in GDP growth has not been accompanied by an increase in employment.

The international agencies are claiming that the Indian economy is booming and the days of slow growth also known as "Hindu rate of growth" is over (Note 4). Since the introduction of neo-liberal economic reforms in 1991, a variable euphoria had swept both inside and outside India. International financial institutions and foreign and domestic media had been largely responsible for this creation. The Goldman Sachs Report (2007), for instance, predicted that within 30 years, “India's economy could be larger than, all but US and China”. The Report further notes that between 2015 and 2025, the size of the Indian economy will pass those of France and Germany and by 2030 that of Japan. And by middle of the $21^{\text {st }}$ century India will overtake China. The Indian growth will exceed $5 \%$ annually for next 30 years and thereafter will continue to grow $5 \%$ per annum (Sachs, 2007).

Rodrik and Subramaniam (2004) argue that India can achieve higher GDP growth rates in the future and most likely outperform China. The main reason for such optimism seem to be that India has got high levels of institutional development than China and it has got functional democracy. The Indian labour force is expected to grow at a faster rate than that of China i.e. faster growth in labour input should lead to a faster output growth (Rodrik and Subramaniam, 2004; Acharya, 2004). Another view suggests that because of new technological development services may in future replace industry as the engine of growth in India (The Economist, 2010; Dasgupta and Singh, 2005).

India's euphoria with the high growth rates of two decades, has given the ruling elites super power ambitions. They ignore the fact that more than one-third of the population live in absolute poverty and the appalling conditions of the country's health sector, which is worse than some sub-Saharan African countries. For example, at present the percentage of underweight children in India is five times that in China. India has long witnessed extensive 
poverty coexistence with rapid growth that increases in output with or without the ISI model.

Bankruptcy of two different capitalist development model i.e. the import substitution model and neo-liberal developmental model, have been tried in both India and Pakistan, but have been unable to resolve the basic problems of the majority of the people in these countries. The contemporary "liberalization" is occurring within the context of the ascendancy of a new form of global financial capital, which has slowed down the rate of growth of the Western economies by rolling back Keynesian “demand management” policies and by encouraging speculation activities in the name of financial innovation over enterprise in the rest of the world. This in turn will adversely affect export prospects of Indian goods. It is also important to note that at present capitalism has entered into a period of protracted global depression. I mean to say that markets in the developed countries are not growing to provide market for Indian goods. China and to some extent India are becoming hostages of their own export-oriented economies given the market in the West is actually shrinking. They are reaching a situation when to continue exporting to the West they have to start subsidizing the Western consumers directly or indirectly. These current measures will be short-term and will not solve the problem in the long run.

It seems that capitalism has failed to remove poverty and inequality despite its long history of penetration in South Asia under colonial and neo-colonial regimes and in spite of being backed by the new technology and increased amounts of credits. The experience of Pakistan clearly illustrated this fact. It is not simply a question of growth rates. There is a lack of discussion about the presence of a large proportion of people living in sub-human conditions and lack of overall and holistic development of human being.

\section{Indian Economy since Independence}

India is currently regarded as one of the "success stories" of globalization and it is often said the country would likely to emerge into a giant economy in the $21^{\text {st }}$ century. The success was linked to high growth rates over the last two decades. According to data the GDP has accelerated from an average around $3.4 \%$ in 1980s to the $6.3 \%$ in 1990 s to an average of $8.5 \%$ during the last eight years. However, the high growth rates in services and also in industry have been associated with an almost stagnant agricultural sector (Siddiqui, 2008). There has been some reduction in the poverty levels but some crucial economic indicators such as those relating to food consumption and nutrition security have deteriorated for significant sections of the population. The rapid economic growth is unable to generate sufficient job opportunities to meet the needs of growing labour force in the country.

During the period 1950-80, economic growth in India was respectable for it was a radical departure from the past and no worse than the performance of most other developing countries. This was because of slow growth of domestic markets which was largely due to rural inequality and low growth of agriculture output and productivity. Therefore, capitalist development depended on expanding public investment, which came to a dead end with the fall of Soviet Union and an increased offensive by the metropolitan capital and international financial institutions. During the period of 1980 and 2009, economic growth in India has been impressive indeed better than many other developing countries apart from China, but the real 
failure in both these periods was the country's inability to transform this growth into uplifting the living conditions of majority of its people.

Table 1 presents data on the key macroeconomic factors e.g. inflation, exports, imports and literacy rates from 2004 to 2009. During the last five years, inflation has increased from $3.8 \%$ to $10.8 \%$, which means cuts in real wages. Exports have doubled during the above period, but at the same time imports have more than tippled and are currently much higher than exports. The literacy rate has not much improved i.e. 64.4 in 2004 to $67.7 \%$ in 2009 (see Table 1).

Table 1. Indian Statistical Summary

\begin{tabular}{|l|l|l|l|l|l|l|}
\hline & 2004 & 2005 & 2006 & 2007 & 2008 & 2009 \\
\hline Inflation (\% change) & 3.8 & 4.2 & 6.2 & 6.4 & 8.3 & 10.8 \\
\hline Birth rate (per ’000) & 25.3 & 24.8 & 24.3 & 23.8 & 23.3 & 22.9 \\
\hline Total exports (US\$ billions) & 75.91 & 96.67 & 121.00 & 143.76 & 177.26 & 153.08 \\
\hline Total imports (US\$ billions) & 97.65 & 136.75 & 171.38 & 216.76 & 289.88 & 234.07 \\
\hline $\begin{array}{l}\text { Infant mortality (deaths per '000 live } \\
\text { birth) }\end{array}$ & 61.7 & 60.0 & 58.6 & 58.3 & 56.9 & 55.5 \\
\hline Adult literacy & 64.4 & 64.5 & 65.2 & 66.0 & 66.9 & 67.7 \\
\hline
\end{tabular}

Source: Economic Surveys, various years, Government of India: New Delhi.

Since 1991 after the adoption of neo-liberal economic reforms (Note 5) the growth rates have risen along with the process of accelerated liberalisation of trade and capital market, but failed to bring any dramatic change in generating employment. This period was also marked by very slow growth in job creation, especially in rural areas.

Growing disproportionately between growth rates of agriculture and non-agriculture sectors during the period of neo-liberal economic reforms has been the feature of development in India. The nature of structural shift in the pattern of recent growth in India compared to the earlier three decades of post independence policies. In the last decade investment in manufacturing has declined considerably, while financial speculative activities in both stocks and bonds have grown enormously. In India currently the service sector is the largest contributor to the GDP, accounts for $52 \%$, while industry contributes $30 \%$ and agriculture only $18 \%$ (Acharya and Mohan, 2010).

During the 1960s and 1970s some developing countries were able to catch-up, which has been accompanied by historically unprecedented levels of investment and domestic savings. As Rodrik (2003) argues, despite unprecedented per capita income growth in developing countries over the period 1960 - 2000, however, only nations of East Asia and some South East Asia were able to do the catch-up. While in other regions, there have been periods of higher than average GDP growth, which they were unable to sustain, hence fall on back in catch-up race (Rodrik, 2003). Contrary to IMF and World Bank prescriptions the East Asian economies did not follow neo-liberal economies policies in order to achieve higher GDP growth rates. In the East Asian countries like Japan and South Korea, the state played a crucial role in shaping and manipulating market forces subjecting both capital and labour to 
strict regulations (Note 6) (Siddiqui, 2009b; Girdner and Siddiqui, 2008; Amsden, 1989).

The expenditures on revenue and capital accounts of the central and state governments on all social services covering public health, medical and education. Central government expenditure, as a proportion of GDP remains well below the peak of 1980. Spending on health and education by the central and state governments has remained unchanged around 6-8 \% of the GDP since 1985 to the present.

The dramatic high rates of GDP growth in China (i.e. of an average $9.8 \%$ annually for nearly three decades) compared to moderate rates of growth in India, which has grown at around 5-6 \% over the last two decades. The higher growth occurs mainly because of higher rates of investment in the economy. Investment as a share of GDP has been between 35 and $44 \%$ over the past three decades, compared to 20 to $26 \%$ in India over the same period. Within this the infrastructure investment has a critical role, which has averaged at $19 \%$ of the GDP in China, but only 2 \% in India over the last two decades. Between 1960 and 2003 East and South Asia's investment and saving efforts was of a different order as compared to India. The economic growth rate is determined by the ratio of investment to GDP. During the 1981 the ratio was $19.7 \%$, which rose to $22 \%$ in 1985, further to $24 \%$ in 1990 . However, during the1990s, it did not increase as was hoped and the ratio of investment to GDP remained at 24\% by 2000 (Economic Survey, 2002). The reason for the rapid rise in growth rates in the 1980s is not largely due to liberalization policies as proclaimed, but in the increase of the investment ratio, which was again not due to Indian capitalists suddenly increasing investment, but due to government decision then to borrow from international institutions to jack up the investment ratio. It is this debt-overhang that precipitated the 1991 crisis by sudden capital outflows and the confidence of international financial institutions had to be restored by adding these neo-liberal economic reforms. The reduction in public investment, which is part of neo-liberal policy packages, is having a damping effect on private investment both by aggravating infrastructural constraints.

Ghosh (2004) summarizes the development in these words: “The economies of South Asia and especially India - are often portrayed in comparative discussion as among the 'success stories' of the developing world in the period since the early 1990s. The sense that the Indian economy performed relatively well during this period may simply reflect the much more depressing or chaotic experiences in the rest of the developing world... Further across the [South Asian] region this growth pattern was marked by low employment generation, greater income inequality and persistent of poverty. In other words, some very apparent success in certain sectors or pockets, on the whole the process of global economic integration did little to cause a dramatic improvement in the material conditions of most of the population, and added to the greater vulnerability and insecurity of the economies in the region”. (Ghosh, 2004: 105-106)

\section{Economic Growth and Poverty in India}

In 1950, the Indian bourgeoisie and the government agreed about the necessity of government planning. It was said that domestic resources would be utilised and Indian dependence on foreign goods and technologies would be curtailed and this would create jobs and income for 
people. It was said ultimately it would 'trickle down' to the poor who would benefit from the employment created by these new economic activities under the public sector (Girdner and Siddiqui, 2008; Frankel, 1978).

After the initial emphasis with the First Five Year Plan on agriculture, a strategy of stressing the acquisition of capital goods and heavy industry was adopted in the Second Five Year Plan. The Second Five Year Plan clearly backed by the desire that state intervention in the industry and infrastructure would be crucial to overall economic growth. At the same time by mid 1960s, the lack of funds and the food crisis continued. The country also announced few 'plan holidays'. The Indian capitalists found ISI strategy profitable to exploit the domestic market as long as local demand kept on rising. However, such policy option ran into difficulty in the late 1960s as the consumers market stagnated along with mounting unemployment and poverty. Despite the protective markets from foreign competitors, the Indian capitalists backed by international financial institutions were openly suggesting abandoning the framework of planning altogether. The market size could be a constraint to growth and increasing inequality puts constraints on growth of the domestic markets through under consumption. The nature of investment demand appears to be closely associated with the income distribution, which is also known as "the market question”. As Kalecki (1976) states, "The crucial problem facing underdeveloped countries is thus to increase investment considerably, not for the sake of generating effective demand but in order to accelerate expansion of productive capacity indispensable for the rapid growth of national income”. (Kalecki, 1976:13) During the post-neo-liberal economic reform period the changes in income distribution may lead to over-consumption of certain sections of the society and resulting decline in government investment expenditure pushes the economy into lower growth path, especially in the agricultural sector.

The Import-Substitution-Industrialisation (ISI) is viewed by the mainstream economists as a costly mistake (Note 7). According to them, the ISI policies were based on the wrong assessment of India's comparative advantage (World Bank, 1997; Ahluwalia, 2002). However, the critical role of the ISI was in kick-starting the build up of technological capabilities in manufacturing, power and engineering industries. It did help the country to significantly upgrade the technical base of the labour force in these sectors. By the end of the 1960s, the stimulus offered by the ISI strategy got exhausted and the ability of the state to continue to provide the stimulus to growth was also undermined. As a result, the economic growth decelerated leading to "secular stagnation" in the 1970s. The state is suppose to fulfil two different roles, which become problematic in the long run - on the one hand to maintain growing expenditures, especially investment expenditures in order to keep the domestic market expanding, while at the same time the exchequer was medium through which large scale transfers were made to the capitalist groups (Byres, 1994). This leads towards fiscal crisis and the state has to cut down while the capitalists demand for alternative policy regime. In the 1980s this impasse was broken which allowed the economy to escape largely due to factors like rise in government spending; liberalization of imports; and finally the state relied on commercial external borrowings to finance government spending. Such policies led to the fiscal and current account deficit crisis in 1991 and India had to seek IMF bailouts (Ghosh, 
2004; Byres, 1994).

The external finance borrowing option was available in the mid-1980s with the rise to dominance of finance capital in the international economy. In the 1980s oil surpluses were deposited in the banks of the developed countries. To borrow money, the government began to rely on funds from international finance and remittances from non-resident Indians. The government also liberalised capital import for industries. This could not continue forever, and by the 1990 began to raise their concerns, which led India into balance of payments crisis of 1991. India adopted IMF/World Bank led Structural Adjustment Programmes(Note 8) to gain the confidence of international finance. This meant further the role of foreign capital inflows; especially financial investment in equity markets became increasingly important. To facilitate such inflows, the regulatory capital barriers were removed to a certain degree. As a result the capital inflows increased. For instance, the foreign capital inflows rose from US\$ 165 millions in 1991-92 to US \$1,374 millions in 1994-95. The rapid increase continued to US\$ 2,439 million in 1999-2000 to US\$ 2,549 in 2004-05, to US \$ 41,315 million in 2008, while it declined to US \$ 34,577 million in 2009 (World Bank, 2010). The increased inflows of FDI are mostly in stock markets or in the forms of mergers and acquisitions by MNEs. It seems that it did not upgrade technologies, nor enhance innovation etc. The inflows are much larger than needed to pay for imports, interest and dividends and thus seeking to absorb this hard currency through exports of capital. The buoyancy and volatility of the stock market and the rise in share prices were seen as symbol of optimism and prosperity rather than employment generation and expansion in the manufacturing sector.

In 2008 capital inflows into India amounted to $9 \%$ of the GDP. The greater part of the capital inflows was from portfolio investment, which was largely due to capital liberalization of rules governing such investments. Capital inflows also increased demand for commercial borrowing by private companies. The domestic firms borrowed more as the constraints on external borrowings were relaxed and also due to the higher rate of interests in domestic market. Net borrowings by Indian domestic companies were increased from US\$ 24.5 billion in 2006 to US\$ 41.9 billion in 2008 (Reserve Bank of India, 2009). But, the foreign capital inflows were only limited to financial sectors and telecommunications. Japan has been one of the top five investors in India, but its share of the total FDI has been dwindling since 2000. Japan's contribution to India's FDI inflows is only $4.3 \%$ of the total FDI inflows between 1991 and 2007. An analysis of sector wise inflows from Japan shows that automobile sector received the maximum FDI during the 2000-07, accounting for nearly $41 \%$ of the total Japan's FDI inflows in India. Other sectors included electrical equipments, services and telecommunications. To attract FDI and open for international capital flows, this will also bring speculative capital (hot money flows).

The strategy of export-led growth would face major problems in the presence of institutional and infrastructural constraints. Any step to increase the export of manufactured goods would lead towards increased demand for food and inputs, which due to institutional and infrastructure barriers India would not be able to meet. As a result, it will lead to rapid inflation, thus eroding further incomes of the majority of the working people. While in the post 1991 neo-liberal economic reforms, the GDP high growth rates in 1991-2009, led by the 
urban middle class and helped by the expansion of credits. The GDP growth in recent years appears to be largely due to debt-fuelled consumption of a small segment of the population rather than increased demand for mass consumer goods. Export growth services especially IT sector remained high. However, exports were not large enough to counter the slow decline of domestic markets. The growth rate started slowing down in early 2008 even before the impact of global slow down on Indian exports. Real GDP growth was $9 \%$ in 2007 but declined to $7.6 \%$ in May 2008. The trade to GDP ratios rose from $11 \%$ in 1995 to $23 \%$ in 2007, while export growth was mainly due to services. For instance, in merchandise the boost of exports were restricted to few sectors like pharmaceuticals, chemicals, metals, textiles, and engineering goods (Reserve Bank of India, 2009).

Since the 1991 economic liberal reforms and increased emphasis on financial liberalization led to financial growth and the state was under pressure to appease financial interests. The international financial institutions are against state deficit financed spending mainly due to the fact that deficit spending is seen to increase liquidity overhang and thus, as being potentially inflationary. And also any increase in deficit spending would mean an implicit legitimization of state intervention, which is anathema to 'free market' ideas.

Empirical studies of agriculture-to-industry relationship are unclear. For example, Rangarajan (1982) analyzed the data of 1960 and 1975 and on this basis he concludes that agriculture did exert a positive influence on industrial growth. While Ahluwalia (2002) found that from 1960-80 the contribution of agricultural to industrial growth was not significant. The growth performance has been accompanied by substantial regional variations in growth during the pre and post neo-liberal reform periods, despite the objectives of reducing the uneven development spelled out in planning documents.

According to UNDP Report (2007: 232) one-third of the Indian people live on just one US \$ per day. Moreover, as a result of inter-regional and inter-sectoral inequalities the socio-economic stagnation in some states is even worse than the aggregate poverty the figures suggest. With the continuing retreat of the state from the economy and the privatisation of the state owned enterprises, the public sector is considered no more as a job creator. For example, the job creation in public sector was at $4 \% 1990$, but fell sharply to $1 \%$ by 2003 (Nagaraj, 2006).

The growth of IT has created jobs only for a small proportion of educated middle classes, but almost has no impact on the unemployment situation. The neo-liberal growth process is primarily driven by the service sector. The services sector contributes $50 \%$ of the GDP, but it only provides $25 \%$ of the total employment (Dasgupta and Singh, 2005). India has became one the of the largest exporter of services in the global economy, as its share in the world exports of IT services reached to $17 \%$ in 2006-07. The share of the service sector has risen sharply, particularly since the adoption of neo-liberal economic policies, which accounting for more that $50 \%$ of the GDP. Moreover, within the service sector, the share of IT has been rising and export of software and communication services amounted to $5.3 \%$ of GDP in 2008 (Reserve Bank of India, 2009). The software and IT industries enabled the service sector, which has become one of the leading segments in the spot liberalization era in India. 
NASSCOM estimates the size of IT sector in India is US\$ 36.6 billion in 2006, of which US\$ 29.5 billion consisted of revenues from software and services. Out of this US\$ 23.4 billion were export revenues. The rate of gross IT sector output to GDP rose from $0.38 \%$ in 1992 to $1.9 \%$ in 2000 and further to $4.5 \%$ in 2005. (Note 9)

If we compare with others for example, we find that the gross revenue from IT services was in 2005 about $20 \%$ higher than the GDP generated in the country's total construction sector. In terms of employment in IT related services, this rose from 0.27 million in 2000 to 0.88 million in 2005. The figures show that the IT sector generated revenues estimated to be $4.5 \%$ of GDP, while it contributed only to $0.21 \%$ of the aggregate employment.

Table 2 shows that after 1991, the growth rates in services rose much faster than manufacturing sector. While at the same time the agricultural growth rates were much lower i.e. $2.2 \%$ in 2007-08. Industry grew faster than agriculture, but slower than services. (see Table 2) India has recently shown rapid growth especially in IT services (i.e. call centers, software, data processing etc.). All these led some observers to claim that India could be 'the next China' given the population size and cheap resources advantages. Perhaps that may be so but the evidence is thin. For example, India's GDP growth rates between 1980 and 2003 are around 5-6\%, was half that of China. However, the growth difference lessened between 2003 and 2008 India's economic grew about $8 \%$, compared with China $10.2 \%$ per annum during the same period. India is the $14^{\text {th }}$ largest manufacturing economy, while China is world's $4^{\text {th }}$ largest manufacturing sector. India is not among the top fifteen world's merchandise exporters, while China is the second largest. More important is India's manufacturing contributes only $16 \%$ of the GDP, while in China it was $32 \%$ in 2008. India does not have a strong export base in manufacturing and China's merchandise exports are eight times larger than India (Siddiqui, 2009a).

Table 2. India’s Macro-economic Indicators (in \%)

\begin{tabular}{|l|l|l|l|l|l|l|l|l|l|}
\hline & 1950 s & 1960 s & 1970 s & 1980 s & $1990-91$ & $\begin{array}{l}1991-92 \\
\text { to } \\
1996-97\end{array}$ & $\begin{array}{l}1997-98 \\
\text { to } \\
2002-03\end{array}$ & $\begin{array}{l}\text { 2003-04 } \\
\text { to } \\
\text { 2006-07 }\end{array}$ & $2007-08$ \\
\hline $\begin{array}{l}\text { Real GDP } \\
\text { growth }\end{array}$ & 3.6 & 4.0 & 2.9 & 5.6 & 5.3 & 5.7 & 5.2 & 8.7 & 8.1 \\
\hline $\begin{array}{l}\text { Agriculture } \\
\text { and Allied }\end{array}$ & 2.7 & 2.5 & 1.3 & 4.4 & 4.0 & 3.7 & 0.9 & 4.9 & 2.2 \\
\hline Industry & 5.8 & 6.2 & 4.4 & 6.4 & 5.7 & 7.0 & 4.1 & 8.3 & 8.6 \\
\hline Services & 4.2 & 5.2 & 4.0 & 6.3 & 5.9 & 6.4 & 7.8 & 10.2 & 10.8 \\
\hline
\end{tabular}

Source: Handbook of Statistics on Indian Economy, various years, Reserve Bank of India, 2009.

Some sectors have done well such as information technologies; where India has emerged as a global centre for software development with sales of $\$ 50$ billion in 2007 (about $5.4 \%$ of GDP) while rose from just $\$ 150$ million in 1990. The service sector's share of GDP increased from $40 \%$ to $55 \%$ between 1991 and 2007, whilst it share of employment remained stable at around $20 \%$ of the labour force. In pharmaceuticals too Indian firms are emerging as a 
credible player on the global markets particularly by selling low-costs drugs in the global markets.

Therefore, it appears that the benefits from increasing incomes since early 1990s have been to small minority of highly qualified employees. The share of IT branch of service sector's share of GDP rose from to about $5 \%$, but it share of total employment contribution is less than $0.25 \%$. At the same time, the manufacturing sector is growing very slowly in terms of GDP share and employment at low levels of $28 \%$ and $12 \%$ respectively (Chatterjee, 2008:4).

During the 1990s as the internal regulatory rules were relaxed in the name of financial liberalization, the private banks began providing credits to finance private consumption and investments (Note 10). The banks went for the most lucrative clients and new avenues of investments with no or poor collateral. As a result, due to financial liberalization, the credit dependence on the Indian economy increased. The rapid growth of demands for automobiles, houses, consumer goods etc. in recent years had been driven by credit-finance purchase.

What has happened since adoption of neo-liberal (i.e. pro-market) economic reforms in 1991 may explain the nature and causes of distributional changes during this period. A number of studies have tended to focus on evaluation of income and consumption after the neo-liberal reforms (Dreze and Sen, 2002; and Dev and Ravi, 2007). It seems that distribution of wealth issues have been overlooked in these studies. The distribution of wealth plays an important role in the development process through its positive contribution in productivity increase (Jayadev et al 2007). Since the neo-liberal reforms the rich states (e.g. Gujarat, Haryana, Maharashtra, Punjab, Tamil Nadu) and middle incomes (e.g. Andhra Pradesh, Kerala, Karnataka, West Bengal) are experiencing much faster asset growth rates annually than poor states (e.g. Bihar, Madhya Pradesh, Orissa, Rajasthan) (Jayadev et al 2007; Kochhar et al, 2006). This perhaps explains greater incentives and ability to save and invest and as a result faster accumulation of wealth in the high and middle income states.

Regarding the changes in the share of wealth, Jayadev et al (2007) finds that "the bottom $80 \%$ of the population seems to have been either stagnant or suffered mild declines where as the upper $20 \%$ has tended to consolidate its holdings. This indicates that India is shinning more brightly on (top) $20 \%$ of its population, a phenomenon noted by several observers”. (Jayadev, 2007:3862)

India's foreign exchange reserve increased rapidly from US\$110.5 billion in 2007-08 to US\$ 309.7 billion in 2008-09. This increase took place mainly because of dramatic rise in the inflows of foreign capital. In terms of the country's need to finance current transactions, it is in a comfortable situation. Despite the global financial turmoil, India has got good reserve levels, which exceeds the value of 10 months imports. It seems that India has come long way from the foreign exchange crisis it experienced in 1991, when India faced a balance of payments crisis with reserve having fallen to just the value of two weeks' imports. However, the mainstream economists when they talk about the high levels of current foreign exchange reserve, they ignore the fact that the current account surplus is not resulting form India's export success, but rather has accumulated because of large foreign capital inflows (quite contrary to what China has done). 
The decade after 1991 the central government's debt has risen from $55.2 \%$ in 1991 to $61.5 \%$ of GDP in 2008. Similarly the state government debt as a percentage of GDP has risen as well as shown in Table 3.

Table 3. India’s Public Debts as Percentage of Gross Domestic Product

\begin{tabular}{|l|l|l|l|}
\hline Year & Central Government & State Governments & Consolidated \\
\hline 1991 & 55.2 & 22.5 & 64.7 \\
\hline 2001 & 56.6 & 28.3 & 70.6 \\
\hline 2004 & 63.0 & 33.2 & 81.4 \\
\hline 2005 & 63.3 & 32.7 & 81.3 \\
\hline 2006 & 63.1 & 32.6 & 80.4 \\
\hline 2007 & 61.2 & 30.2 & 77.0 \\
\hline 2008 & 61.5 & 28.4 & 77.0 \\
\hline
\end{tabular}

Source: Reserve Bank of India, 2008, Annual Report, Table 2.41; also Economic Survey, 2009, Government of India.

It will useful to briefly look at the regional impact of the neo-liberal reforms in India. India's most populous states, namely the Hindi-speaking region of north and central India continue to represent the least economic developed region of India. There is a wealth of literature on regional disparities focusing on economic pre-condition for growth and much of recent literature on regional patterns of growth in India is concerned with the impact of liberalization and economic reforms on growth. The debate on interstate growth trends has been summarized as: "the low income and poorly performance major states of Uttar Pradesh, Madhya Pradesh, Bihar, Orissa and Assam, have not only persisted with their low growth syndrome but have also experienced further deceleration in growth rates in the 1990s... It is for this reason that, despite an improvement in the growth rates on many middle income states, the degree of dispersion in growth rates as measured by the coefficient of variation (cv) has widened in the 1990s”. (Economic and Political Weekly, Research Foundation 2004: 26)

Similar disturbing trends were seen in terms of per capita income. The gap between poorer and richer regions has grown in recent years. Per capita average income in western states was 3.8 times that of eastern states in 2000. Further, all the seven states in the less developed regions have a per capita income below the national average, while all eight states in developed states have a per capita income above the national average. The incomes of the poor states grew at lower rates than the national average and also population growth was significantly higher in these states as compared to richer states. Indeed, the per capita income growth in real terms for Bihar state was negligible during the last decade. It seems the gap between developed and less developed states in India has widened during the last decade. Indeed, in respect of certain other indicators of economic prosperity like availability of telephone, public transport, and communication etc. the gaps have widened even further (Kurian 2002).

For example, the NSS (National Sample Survey) data (Note 11), which are conducted under the direction of Planning Commission, shows that absolute poverty in India declined from $54 \%$ in 1974 to $43 \%$ in 1984 and declined further to $36 \%$ in 1994. The NSS surveys result 
show that during the 1973-83, per capita GDP grew at an average rate of only $2 \%$ annually, but absolute poverty declined by 10.1 percentage points. However, between 1983 and 1993, per capita income grew at an accelerated rate with rates of growth of 3 percentage annually and poverty declined by almost an identical amount of 9.9 percentage points. The growth rate is $50 \%$ higher in the second period compared to first period, but decline in poverty rates are similar. It means higher growth rates does not mean rapid decline in poverty levels.

India has witnessed extensive poverty along with rapid growth. It continues to have more than one-fourth of its population living in absolute poverty (Sundaram, and Tendulkar, 2003). In spite of the fact that India continue to import more than exports and its comfortable foreign exchange reserve position is largely as a result of accumulated portfolio investments and short-term inflows. In order to keep this process, India needs to comply with the requirements of financial markets through the fiscal and monetary policies. At the extreme end of income distribution the picture that emerges is one of the striking contrasts. According to the Forbes magazine list for 2007, the number of Indian billionaires rose from 9 in 2004 to 40 in 2007. However, much richer country like France had only 14 and Japan 24. The combined wealth of Indian billionaires increased from US\$ 106 billion to US\$ 170 billion in a single year i.e. 2007 (Jain and Gupta, 2008).

There was a sharp rise in saving rates between 2004-05 and 2007-08. Since it is the richer sections that have incomes that are substantially in excess of their consumption needs which can be saved, this sharp rise in the savings rate points to an increase in incomes among the richer classes. There has also been a shift in the source of savings in the economy away from the household to the corporate sector. The share of the corporate sector in gross domestic savings rose from 20.4 per cent in 2004-05 to 24 per cent in 2007-08, while that of the household sector fell from 72.3 to 62.2 per cent. Thus the period witnessed a sharp rise in private saving that largely came from the corporate sector, which has been recording significant increases in profitability at a time when the average real wage rate in the organised manufacturing sector has been stagnant (Siddiqui, 2010b).

Some have criticised the accuracy of the poverty estimates because of the change in methodology for the data collection (Note 12). The official calculations are based on the NSS data and no attempt has been made to correct it for any of the deficiencies. Two patterns could be observed from the NSS data. The first is that the superior performance of the southern and western states relative to those in the north and east. In rural Tamil Nadu, for example, nearly half of the population lived below the poverty line in 1988; while in 2000, it was only a quarter (Deaton, 2003).

The rapid economic growth over the past two decades has not addressed the issues of food security and nutritional levels. The recent National Family Health Survey (NFHS) conducted in 2005-06 finds that $46 \%$ of the children aged below three years are underweight, about one-third India's population have their Body Mass Index (BMI) below normal. The average daily intake of protein, which is considered very important for people with vegetarian diet, has declined from 60.2 to 57 grams in rural areas between 1993-94 and 2004-05 and remained stable around at 57 grams in the urban areas during the same period. According to 
National Sample Survey (NSS) of 2004-05 the average daily intake of calorie of rural population has decreased by $106 \mathrm{kcal}$ (4.9\%) from $2153 \mathrm{kcal}$ to $2047 \mathrm{kcal}$ from 1993-94 to 2004-05 and by $51 \mathrm{kcal}$ (2.5\%) from 2071 to $2020 \mathrm{kcal}$ in urban areas. Barbara Harriss-White (2003) concludes in her study that the neo-liberal economic reforms offers little to the $88 \%$ of the population who live outside of the metropolitan cities of India and work largely in the informal economy of agriculture, services and small scale industries.

There are reasons to believe that economic policy of neo-liberal economic reforms especially in terms of more open trade and capital accounts for the pattern of manufacturing growth under an open economic regime tends to be such that responsiveness of employment growth to growth in output declines (Patnaik, 2010). An important reason for this could be the impact of trade liberalization on the pattern of demand for goods and services. It seems that the tastes of upper income group influenced by the life style of the rich countries. The new luxury items introduced in the western markets very quickly find their way to India when its economy is open. Also higher productivity achieved in the form of new products, the producers in trade would experience pressure of external competition and thus would require to adopt, such technologies which would increase the levels of mechanize and thus ultimately less job creation (Patnaik, 2007).

\section{Neglect of Agriculture Sector}

The share of agriculture in the GDP has steadily shrunk from $42.3 \%$ in 1971 to merely $17.8 \%$ in 2009. Public investment in agriculture declined from $3.4 \%$ of agricultural GDP during the 1976-77 to $2.6 \%$ during the 2005-06. More than 100, 000 farmers have taken their lives according to official information between 1998 and 2009, which indicates the nature of desperation on the agrarian front. Agriculture growth has lagged far behind the growth of services and manufacturing sector. The current economic policy of liberalization has to some extent contributed to this and also due to decline in the returns from 'green revolution' technologies. The adoption of new liberal polices have reduced the amount of public investment in agriculture. For example, the cut backs in input subsidies and credits to small farmers along with the introduction of trade liberalization, caused agricultural prices to fall for some products, which some have described as “double squeeze”. (Vakulabharanam, 2010)

The strategy adopted to modernize agriculture in mid-1960s also known as 'green revolution' was to create a class of surplus producing farmers, who were able to produce surplus on the basis of subsidized inputs and low wages as well as price support (Siddiqui, 1999a). However, in the 1990s agricultural sector growth was either stagnant or grew at much slower rates compared to previous decade. Agriculture production increased at an average rate of $2.2 \%$ per year between 1991 and 97 compared to $3 \%$ during the pre-reform period of 1983-90. Moreover, the growth of food production has declined sharply and even fell below population growth (Siddiqui, 1999b). For example, during the 1979-90, the annual growth rate of food grain output was $2.4 \%$ per year. But after neo-liberal economic reforms between1991and 1997 this declined to average $1.4 \%$ per year. 
Table 4. Growth rates of GDP, agriculture and non-agriculture sectors in various periods at 1993-94 prices (percentage per year) in India

\begin{tabular}{|l|l|l|l|}
\hline Period & Total GDP growth & Agriculture & Non-agriculture \\
\hline $\begin{array}{l}\text { Pre-green revolution } \\
(1950-1965)\end{array}$ & 3.9 & 2.6 & 5.5 \\
\hline $\begin{array}{l}\text { Green revolution period } \\
(1966-1980)\end{array}$ & 3.6 & 2.8 & 4.4 \\
\hline $\begin{array}{l}\text { Wider technology } \\
\text { dissemination period } \\
(1981-1995)\end{array}$ & 5.3 & 3.3 & 6.5 \\
\hline Post reform (1996-2008) & 6.6 & 2.6 & 7.8 \\
\hline
\end{tabular}

Source: Economic Survey, various years, Government of India, New Delhi.

Table 4 shows the growth in agriculture sector, which was a higher during the green revolution period (1966-80) than pre-green revolution period (1950-65). However, we find that agricultural growth rates have declined (see Table 4). Agriculture sector grew by only $0.2 \%$ in 2009-10, after a slow growth of $1.6 \%$ in 2008-09 (see Table 4). Moreover, foodgrains production fell by $7.5 \%$ in 2009-10 over the last year. The fall in public investment in the agricultural sector in the 1990s has contributed to the current crisis in the agricultural sector (see Table 5). The rate of growth of food grain production is lower even the rate of population growth for the last two decades and the rate of industrial growth have been less than encouraging. In the 1990s compared to the preceding decade, industrial production has been lower. Industrial recession, because of reduced aggregate demand and competition from imports had adverse effect on employment in manufacturing sector.

As Table 5 shows that per capita production of food grains has declined especially in the neo-liberal economic reform period (1991-2009). Moreover, the production of pulses per capita has steadily declined i.e. $19 \mathrm{~kg}$ in 1971-75 to only $13 \mathrm{~kg}$ in 2006-09. In India most of the population is still vegetarian and pulses are very important source of proteins. Therefore, falling per capita production in pulses sends an alarming signals (see Table 5).

Table 5. Per capita production of food grains, 1971-2009 (in kg)

\begin{tabular}{|l|l|l|l|}
\hline Year & Cereals & Pulses & Foodgrains \\
\hline $1971-75$ & 164 & 19 & 183 \\
\hline $1976-80$ & 172 & 18 & 190 \\
\hline $1981-85$ & 179 & 17 & 196 \\
\hline $1986-90$ & 182 & 16 & 198 \\
\hline $1991-95$ & 192 & 15 & 207 \\
\hline $1996-2000$ & 191 & 14 & 205 \\
\hline $2001-05$ & 177 & 12 & 189 \\
\hline $2006-09$ & 174 & 13 & 184 \\
\hline
\end{tabular}

Source: Economic Survey, various years, Government of India, New Delhi.

Progress in agriculture is hindered by falling levels of public investment, poorly maintained 
irrigation systems and inadequate roads. Less than one-third of all crop land is irrigated and most farming is at the subsistence level. The sector's performance has crucial consequences for the country's poor. Farm productivity is very low. Farm output rose by only $0.7 \%$ in the first quarter of 2010 but the government predicts gains of 4.7\% in the 2010/2011 fiscal year. Manufacturing accounts for approximately $14.4 \%$ of GDP. Real growth in manufacturing fell to $6.3 \%$ in 2009. However, producers of consumer products expect a strong rebound in 2010 . So far, inventory restocking has provided most of the support for struggling manufacturers. Increased spending on technology in industrialized countries in 2010 should boost growth in India's high-tech producers are services. The service sector has experienced slower growth but remains healthy. The country's export-oriented information technology and business process outsourcing industries face mounting competitive pressures and slowing demand.

The agriculture sector's share of GDP has decreased sharply since 1991 from $35 \%$ to mere $17 \%$ in 2009, whilst nearly $60 \%$ of the population continue to depend on agriculture sector. The data in terms of total consumption of cereals is presented in Table 6 for various countries for 2005. For India, we present data for 1991 as well so that we can analyse the trends in cereal consumption since the adoption of neo-liberal reforms. As the data indicates the total per capita cereals consumption has declined $180.1 \mathrm{~kg}$ per in 1991 to 169.3 in 2005. If we compare India with other developing countries such as China and Mexico, we find average per capita consumption is lower in India (see Table 6). After neo-liberal economic reforms were introduced in India there has been hardly any empirical in-depth study on India to examine its impact on economic and social change. An attempt has been made by Utsa Patnaik (2010), who found that after 1991 neo-liberal reforms were introduced, the inequalities have risen between various sections of Indian society.

Table 6. Direct, indirect and total consumption of cereals in selected countries, in 2005 (in kg per capita) and total calorie intake per capita per day

\begin{tabular}{|l|l|l|l|l|l|l|}
\hline \multicolumn{7}{|c|}{ Cereal Consumption } \\
\hline & Direct & Indirect & Total & $\begin{array}{l}\text { Direct } \\
\text { consumption }\end{array}$ & $\begin{array}{l}\text { Indirect } \\
\text { consumption }\end{array}$ & $\begin{array}{l}\text { Calorie } \\
\text { intake }\end{array}$ \\
\hline India 1991 & 162.1 & 18.0 & 180.1 & 90.0 & 10.0 & 2,316 \\
\hline India 2005 & 148.9 & 20.4 & 169.3 & 87.9 & 12.1 & 2,235 \\
\hline China & 155.8 & 130.0 & 285.8 & 54.5 & 45.5 & 2,974 \\
\hline Mexico & 170.2 & 278.4 & 448.6 & 37.9 & 62.1 & 3,223 \\
\hline Russia & 152.1 & 328.5 & 480.6 & 31.6 & 68.4 & 3,376 \\
\hline Germany & 114.8 & 392.9 & 507.7 & 22.6 & 77.4 & 3,524 \\
\hline United States & 109 & 815.7 & 924.7 & 11.8 & 88.2 & 3,796 \\
\hline
\end{tabular}

Notes: Indirect uses include feed grain, seed, processing and others. For India 1991 values are also given. Calorie intake is per capita per day from all food and is given in FAO for each country. As with cereals, net export and other use of animal products, vegetables etc. are taken into account while calculating calorie intake of the domestic population.

Source: Usta Patnaik (2010) “On some fatal fallacies”, in Economic and Political weekly, Vol.xiv, no.47, 
pp.82, November 20, Mumbai.

The agriculture crisis has worsened since the adoption of neo-liberal economic reforms. As a consequence, the country is experiencing an agrarian crisis. The main reason for this acute situation is the reduction of state support for agriculture sector. The real per capita wages in agriculture have stagnating or declining since 1991, while grain prices are rising and more land is allocated for the production of cash crops, resulting in decreased consumption of the food commodities. For example, the agriculture sector has suffered the worst and this reflects in the reduced consumption shares of rural population especially small and marginal farmers and agriculture workers (see Table 6). It appears clearly that the Indian growth strategy has tended to leave the majority of the population behind especially in rural areas (Vakulabharanam, 2010).

Moreover, the variations within the states appear to be widespread. For instance, International Food Policy Research Institute (IFPRI) (2008) on Indian Hunger Index indicates very large differences across states in India ranging from 30.9 for Madhya Pradesh, 27.3 for Bihar, 23.3 for Karnataka, 22.8 for Maharashtra, 17.6 for Kerala to 13.6 for Punjab. Some richest states with rapid GDP growth such as Gujarat, Karnataka and Maharashtra perform very poorly on hunger index i.e. much worse than Kerala (IFPRI, 2008) India State Hunger Index). Bihar on the Hunger Index Rank is 15, Jharkhand 16, Chattisgarh 14, which is lower than Zimbabwe and many Indian states rank fall around sub-Saharan African countries (IFPRI, 2008).

With the adoption of neo-liberal economic reforms in 1991, the rural poverty rose from $25 \%$ to $36 \%$ within just one year (i.e. 1991-92). It was only brought down to earlier level by government intervention (Tendulkar and Jain, 1995; Basu and Mallick, 2008) Sarkar and Mehta (2010) have concluded in their study of income inequality in pre- and post reforms periods. According to their findings, "A clear picture emerges from the analysis that the labour market generates a difference in wages and income based on residence (rural or urban), employment status, educational level, industrial groups and gender. However, in urban areas, the wage gap between secondary and tertiary (services) sector was widening probably reflecting the service-oriented pattern of economic growth. The overall income inequality (gini-coefficient) demonstrated a continuous increase over the period with a sharp increase during the post reform period.... The sectoral composition stated that the tertiary sector and construction has provided the bulk of new opportunities for growing labour force. The enhanced role of construction is a feature of the post-reform growth process”. (Sarkar and Mehta, 2010: 54-55)

The adoption neo-liberal reforms resulted into reduction in government spending and a shift in income distribution against working people is taking place. Sen (1996) has found the rural poverty is closely linked with factors like government development spending in rural areas, the ratio of grain price index to the wholesale price index and the availability of jobs outside agriculture sector. As these have moved in a direction, which has put rural poor into disadvantaged situations. The agriculture sector is crucial where more than two-third of the population continue to live in rural areas. The economic restructuring of India and its 
modernization process, has highlighted so far only the GDP growth rates and neglected the over all rural sector growth. For all boost in services and IT expansion, India remains one of the most rural economies in the world, with majority of its people dependent on jobs in stagnant or neglected agriculture sector. India's agriculture crisis has resulted in a high number of suicide rates among farmers. If the reform is aimed to make the Indian economy more globally competitive state intervention becomes very crucial as did happen in Japan, South Korea (Amsden, 1989) and more recently in Malaysia. Therefore, the role of state to intervene in the economy to cushion the impact the inevitable unemployment and inequality that such technological change and global integration has caused. Contrary to this, what we find, the government has pulled back from playing this role. For example, government spending on rural development and social welfare has been cut as a result rural poverty has risen in recent years.

Despite the talk of land reforms and land-to-the-tillers curbing of concentration of rural economic power did not change radically and not enough was done to alter the situation. As a result asset and income inequality in rural India continued. As a consequence, the expansion of markets for mass consumption goods were limited and the large number of small farmers and tenants were unable to increase investment and productivity in the land. Therefore, under these circumstances state spending was seen as essential for the growth of markets and to create employment. The stimulus for growth was seen through state investment in the economy.

\section{Trends in Employment in Indian Economy}

In contrast to earlier times, when less than $4 \%$ growth was associated on average with a $2 \%$ growth in employment. At present, India is experiencing GDP growth rates of more than $7 \%$ per annum, but the employment growth has hardly exceeded $1 \%$. This means most of growth does not create any job but of higher output per worker. As far as rural poverty is concerned, the percentage of people not able consume enough food i.e. 2400 calorie daily intake (as officially suggested) increased from $75 \%$ in 1993-94 to $87 \%$ in 2004-05. High GDP growth rates have not make any significant impact on hunger and malnutrition in rural India.

Rural poverty ratio has not declined despite of high growth rates for more than two decades. This has happened in the midst of massive accumulation of unsold foodgrains stocks, which has increased despite declining per capita output levels. Real wage growth did not increase after 1991 and growth has been highly inequitable - inequality between regions and between classes has significantly increased. Inequality has grown in India between 1993-94 and 2004-05 the co-efficient increased from 0.25 to 0.27 in urban and from 0.31 to 0.35 in rural areas.

We must examine the growth of employment in various sectors over the last three decades as shown in Table 7. The data indicates that the share of primary sector in the total employment (60\%) much larger than the share in GDP i.e. $27 \%$. There was a small increase in the manufacturing sector employment from $13.8 \%$ in 1982 to $16.8 \%$ in 2000 . In agriculture, the greater use of mechanized techniques of cultivation, have reduced the demand for labour per unit of output. Also the slow down in employment growth was due to reduction in 
government expenditure which has direct employment generating effect (see Table 7).

Table 7. Share of Agriculture in Output and Employment in India (1980-2009)

\begin{tabular}{|l|l|l|}
\hline Year & Share of agriculture in GDP & Share of agriculture in Employment \\
\hline $1980-81$ & 35.7 & 60.5 \\
\hline $1990-91$ & 29.2 & 59.0 \\
\hline $2000-01$ & 23.3 & 58.4 \\
\hline $2008-09$ & 15.7 & 52.1 \\
\hline
\end{tabular}

Notes: Agriculture includes crops, livestock, fisheries and forestry.

Source: Economic Survey, various years, Government of India: New Delhi.

The latest National Sample Survey (NSS) estimates of employment and unemployment in the country indicate that in an overall complex employment picture the rate of job creation during the years of rapid growth has been poor. The 2004-05 NSS survey suggested that 12 million jobs had been created every year or an employment growth of 2.8 per year between 1999-2000 and 2004-05. "The aggregate employment in the primary sector declined in absolute terms, the growth rate of employment in the secondary sector and services were only 1 \% per annum”. (Economic and Political Weekly, 2010, P.7)

The pattern of growth of the service sector, which is an important source of growth since the neo-liberal reforms were launched in 1991, the employment growth in this sector was slower than the growth of output. Thus, agriculture sector does not play any crucial role in current growth process and is excluded from current phase of development in India.

The pattern of growth in manufacturing sector under an open economic regime is such that the responsiveness of employment growth to the growth in output tends to decline. As Patnaik (2007) argues the combination of high output growth and low employment, is a feature characterize by India during the period it has adopted neo-liberal economic polices and opened its economy to trade and investment.

The sectoral distribution of employment shows that agriculture sector dominates. We are looking at short period data on unemployment. As is to be expected given the short period of time involved, there have been no major changes in the structure of employment between 2004-05 and 2007-08, except for a rise in the share of construction among rural males. Thus the trends in the structure of employment prior to 2004-05 have been more or less sustained. An important feature of this was the significant decline in agriculture as a share of rural employment, even as the share of manufacturing employment did not go up commensurately for rural male workers. The share of manufacturing employment has stagnated in the urban areas as well. While there has been some shift to construction, the share of trade, hotels and restaurants seems to be stagnating. Casual wage labour and self-employment dominate the employment scenario.

There a number of features of post liberalization growth period such as growth is unevenly distributed across various sectors and regions, with an high share of it being contributed by service sector, despite high growth rates, the employment has not been growing and large 
proportion of those employed are concentrated in the slow growing and low productive sector. Finally, despite two decades of high GDP growth a large number of people are desperately poor. The Human Report of the United Nations ranks member countries with weights given to parameters such as provisions for food, nutrition, health and education facilities. India occupies at the bottom of 127 on that list.

India's export earning from IT related services rose from over US\$ 2 billion in 1992 to 11.6 billion in 2002 and rose further to US\$ 58.4 billion in 2007. It was assumed that a major proportion of this export earnings would be spent on purchase of domestic produced goods and services. But these incomes were hugely spent on imported goods. In fact the export-led growth in India has led to corresponding rise in imports and thus very little that is being generated is trickling down to the poor sections of the population. (Note 13) Neo-liberalism actually hinders the state from playing the role of an income equalizing via fiscal and monetary polices. Stagnation in agriculture is partly due to scaling down of public investment, leading to deterioration of rural infrastructure.

What this assessment ignores is, of course, the question: Growth for whom? As has been repeatedly noted but inadequately stressed, the fact is that India is a country still plagued by hunger with among the highest rates of malnutrition in the world. Deprivation in other forms such as lack of access to clean drinking water, sanitation, basic health facilities and school education still afflict a large proportion of the population.

The 64th Round of the NSS relating to 2007-08, which had migration as its focus but covered employment and unemployment as well, does provide us with an additional source of data. We must recall that the late 1990s was marked by a dramatic deceleration of aggregate employment growth, which fell to the lowest rate recorded since such data began being collected in the 1950s.

\section{Pakistan's Economy: Growth and Crisis}

In this section I will discuss the development of Pakistan's economy and its performance in the last six decades and also the influence of United States policy since early 1950. Despite some impressive GDP growth rates, the fruits of the so-called development have by passed the majority of the people. The question arises what are the sources of this growth? And who have been its primary beneficiaries? Why for the last two decades has Pakistan faced recurrent balance of payments difficulties? Is it due to structure of production and exports? I would also look at the long evolution of Pakistan's economic policies from the days of General Ayub Khan and touch upon the structural weaknesses of the economy.

At independence in 1947 Pakistan inherited some skills from colonial administration and army, but there was a severe shortage to finance the running of the day-to-day government and also to rehabilitate millions of refugees from India. The country was largely an agrarian nation with hardly any manufacturing sector. In the early years, the main concern was the difficult situation with its neighbour i.e. India. Moreover, on organizational levels the Muslim League, the party which campaigned for a separate Muslim state, was weak, especially in West Pakistan. The state power was predominantly in the hands of military and civil servants 
as the Muslim League was unable to organize at grass roots. The party had drawn its leadership largely from civil servants, large landholders, merchants and tribal chiefs. Muslim League witnessed great difficulty after its founder M.A. Jinnah died in 1948 and the Prime Minister Liaquat Ali Khan was assassinated in 1951 (Gardezi, 1991).

Here it will be interesting to emphasize that at the end of the Second World War few colonial countries were able to make a clear break from their colonial structures. Pakistan clearly retained most of the colonial structures. With the end of direct rule after the Second World War the metropolitan and periphery economic exploitative relationship did not end. During the colonial rule, the colonial government was involved directly in the process of accumulation and transfer of economic resources from the colonies to the metropolitan countries. In the late $19^{\text {th }}$ and $20^{\text {th }}$ century export of capital from metropolitan integrated the colonial economy with the metropolitan capital in a subservient position (Gardezi, 1991). With the end of colonial rule, it was hoped that these will change, but it appears that the colonial relationship did not disappear. As we witness in Pakistan it simply went through the process of adoption to adjust under new circumstances.

In the early troubled years, in Pakistan in the absence of national bourgeoisie, the big landowners, military and bureaucracy formed alliances. Such situation suited the new imperial power i.e. United States very well. Thus, Pakistan and United States entered into various military agreements, which allowed the US to set-up bases in Pakistan against Soviet Union. In 1950s Pakistan joined US-led military alliances namely SEATO in 1954 and later on CENTO in 1959(Note 14), which brought its military further closer to Pentagon. With General Ayub taking over power in 1958, the US intervention did not limit itself to military only, but intensified to economic affairs as well. As summarized by Gardezi (1991) "Dependence of foreign aid increased to enormous opportunities, with the process of economic planning becoming completely dominated by foreigners-particularly the largest contingent from Harvard University-and Pakistani rapidly moved into the position of new type of economic colony... The role of foreign advisors and planners was only the beginning: Pakistan became one of the biggest employers of foreign technicians, while at the same time [a] large number of Pakistani technicians and scientist were being forced to leave the country". (Gardezi, 1991: 30) From independence onwards the ruling elites (Note 15) set up to work either defending the territorial integrity or economic development. Of course the ruling elites opted for the former. The US needed a strong military in the region to be able to defend their interest in the Middle East and in the North against the Soviet Union. As Jalal (1990) argues by 1951 the United States', “policy statement on Pakistan ... made explicit what had always been implicit, namely that the kingpin of US interests in Pakistan was its army”. (Jalal, 1990: 127)

However, the fear of being taken over by its big neighbour i.e. India was often exaggerated, which led to them to prioritize army rather than economy. Territorial defence rather than industrialisation were given priority, due to increased conflict with India, particularly on Kashmir issue. In the 1950s South Asia became strategically important for the US when Iran's elected government led by Musaddiq nationalized foreign oil companies. The US and UK opposed Musaddiq's policy of promoting national resources and they overthrew Iran's 
democratically elected government in 1953. The US was looking for local allies and Pakistan civil and military elites were already looking for some opportunities to forge close alliances with the US. Various arms assistance was signed with Pakistan. In return for military aid Pakistan territories to be used for US interest in the region (Alavi, 1998; Jalal, 1995).

On the economic front, the country launched Import-Substitution-Industrialisation (ISI) policy in the 1950s. In the first decade i.e. 1947-1958, Pakistan's GDP grew at the average rate of $3.1 \%$ annually, a head of population growth rate. During this period foreign capital inflows were insignificant and it was mainly limited to technical assistance. During the 1960s the average growth rates in the manufacturing sectors was quite high and General Ayub's government called this as 'Decade of Development'. However, the broader consequences of the economic policies are important to take into account. As Ahmed and Amjad find, "This period of rapid economic growth, achieved mainly as a result of the policies pursued, generated a great deal of economic tension ... Increasing disparities in regional income between provinces, a concentration of industrial economic power the failure of real wages to increase significantly”. (Ahmed and Amjad, 1984: 77) However, the agriculture sector during this period experienced stagnation or negative growth. The agriculture growth rates were lower than the growth in population during the same period. As a result per capita food consumption fell in real terms. The dismal performance in agriculture sector also meant that the potential market for manufacturing sector was also stagnated, restricting further growth of manufacturing sector. In the 1960s central planning and state intervention was seen as to assist ISI model and was widely supported by the government.

By the 1950s and 60s various industries were set up on the basis of Import- Substitution Industrialisation mainly to produce consumer goods for local elites with capital and resources supplied both by the state and foreign capital. The development strategy was formulated by a group of Harvard University economists and Pakistani civil servants who had received brief training in the US. Officially it was conceived within the framework of Five Year Plans. It aimed to create entrepreneurial spirit by offering them various incentives such as tax holidays, foreign exchange bonuses, subsidies and cheap loans. While such policies produced high GDP growth rates, the majority of the people witnessed decline in the living conditions. The GDP growth rates, for instance, rose from $3.1 \%$ in 1956 to $6.8 \%$ in 1966 and further to $10 \%$ in 1970 .

During the first half of the 1960s import policy was eased due to availability of foreign aid, which increased from $2.5 \%$ of GNP in 1956 to 7 \% of GNP in 1964 (Amjad, 1982:5). In fact, The Asian Development Bank study (1985) had emphasized that the, "Import liberalization which took place during the first half of the 1960s would have been impossible without this large increase in aid”. (Asian Development Bank, 1985: 359) However, after the Indo-Pak war in 1965 the availability of foreign aid declined, which resulted in cutbacks in imports.

In fact, in the beginning years of General Ayub's rule, the profits for the domestic and foreign companies rose dramatically, while at the same time wages stagnated and even declined in real sense because economic downturn due to saturation in domestic demands for consumer goods. In the 1950s and 1960s the rapid growth rates was dependent on foreign aid and 
government support to business. Growth was seen as important by the neo-classical economists who suggested that the high growth would eventually 'trickle down' to the people (Easterly, 2001). The Harvard economists emphasized that the rich would generate savings and ultimately invest leading towards job creation and overall growth, but it did not happen. Moreover, during the 1960s the disparities across classes and regions widened. The public spending on social sector did not witness any substantial rise. There was stagnation or little increase in real wages in organised sector (Gardezi, 1998).

The government took initiative to support the expansion of industries mainly in export sector through the Export Bonus Scheme. It adopted Export Bonus Scheme (also known as Export Boucher Scheme) in 1959 which critiques find was largely responsible for high growth rates in the early 1960s. This was used both to subsidize exports and lessen import controls. The scheme did provide additional income to certain percentage of their export earnings (i.e. percentage varied from year to year and from commodity to commodity). The export under the Bonus Scheme acted as import licences. The critiques have argued that the boom in private industrial investment in the first half of the sixties and its subsequent decline took place largely due to change in foreign aid inflows to manufacturing sector. As Amjad explains (1982): "The system which operated in Pakistan came very close to being what we can term a 'Foreign Aid Dependent Regime' in which the mechanics of industrial growth are in one way or another made dependent on foreign aid inflows. Once these aid flows slowed down, the system, not being able to replace foreign aid with other forms of external finance like direct foreign investment, and without the peculiar boost to profitability associated with the local system for dispensing aid, found it difficult to sustain the earlier growth it had generated". (Amjad, 1982:166)

The economic policies pursued during General Ayub's regime led to the further worsening the levels of inter-regional disparity between East and West Pakistan. It was said the resources had been transferred from the East Pakistan and all development that had taken place only in the West Pakistan. Also the levels of per capita income $10 \%$ higher in West Pakistan than in East Pakistan in 1950, but this disparity had risen to over $30 \%$ in 1966. And in 1971 East Pakistan became a separate nation as Bangladesh (Gardezi, 1991). The West Pakistan was able to successfully export to the market in East Pakistan. However, after the secession of East Pakistan 1971 large market was lost, as 50 \% of the total West Pakistan's export and $20 \%$ of its imports were from East Pakistan. The economy experienced a big shock to find new market for its exports and four-fold increase in petroleum prices (Gardezi, 1991).

Zulfikar Ali Bhutto came to power after the collapse of the military regime in 1971. His emphasis was rapid on industrialisation in the public sector and this laid foundation of heavy industries such as steel mills and nationalization of many private industries to increase state's role in the economy. The main stream economists have often cited Zulfikar Ali Bhutto regime's (1971-77) for putting policies which led to low growth and higher inflation (Easterly, 2001; World Bank, 2006; Gardezi, 1991). Let us examine the economic performance in the light of the facts. It is crucial to look at Bhutto's government performance under the circumstances and the problems he inherited. Private investment was already falling during the last years of Ayub's regime. After coming to power Bhutto nationalized banks and 
manufacturing industries, which he saw it as crucial industries with national importance and should not be left into the private hands. The Export Bonus Scheme was also withdrawn. Zulfikar Ali Bhutto government's first two years did witness impressive growth. The agriculture output rose largely due to tighten control over nationalized banks more credits were available to small farmers and medium enterprises. However, the last three years, which coincided with big investment in key industries with long-gestation period, but economic growth slowed down sharply in both agriculture and manufacturing sectors. There was wide spread mismanagement and lack of accountability in the nationalized industries and lack investment did not the help the situation. The nationalization of the key industries further discouraged them to invest, created fear among the private investors (Amjad, 1982; Zaidi, 2005).

Zulfikar Ali Bhutto's economic polices of nationalization of key industries such as banks, steel mills, insurance companies etc. was important, but lacked any long term commitments on how these sectors would contribute towards the modernization of Pakistan's economy. Even mangers appointed by the government to run these public companies had no enthusiasm, nor capital to modernize and improve productivity and efficiency. As a consequence, these industries soon experienced decline in productivity and profits. Thus, due to mismanagement, lack of funds and motivation, the crisis in nationalized industries deepened. However, the nationalization programme of Bhutto government did manage to increase public sector employment. In fact, when Bhutto government was removed, the development spending in 1976-77 was quite high as $11 \%$ of GDP, the highest ever in Pakistan's sixty years history. The nationalization of banks resulted in growth of number of branches in rural areas by $45 \%$ as a result it witnessed 11-fold expansion in credits to agricultural sector (Amjad, 1982).

It will be interesting to look at global economic situation during the Bhutto tenure. In 1973 fourth-fold rise in petroleum prices, the import costs of petrol, petroleum products and fertilizers rose sharply, which led to sharp price rise in the domestic markets. It was also followed by world recession, as a result the demand for exports were depressed. All these international events were beyond control of the government. The prices rose to very high levels to $30 \%$ in 1973-74. Due to global recession in 1973-74, the export dropped further, while rise in import prices led to dramatic rise in import bills. Moreover, the flood in 1974-75 damaged agricultural crops especially cotton, as a result export revenue declined because cotton use to be the key export item. This added to the problem and due to lack of fiscal and monetary discipline leading to high deficit budget, monetary expansion and inflation rates reached to new heights (Zaidi, 2005).

General Zia-ul-Haq removed Bhutto in a military coup in 1977 and when, in 1979, the Soviet Union invaded Afghanistan, the US provided huge military and economic aid to Pakistan. The US supplied military assistance to Mujahedeen (holy warriors) through Pakistan. General Zia found it useful to maintain to the religious theocracy and extremist religious ideology to prolong his authoritarian rule. This was because most people are quite religious in Pakistan. During the 1980s Saudi Arabia and the Gulf States also provided massive finance to Madarssas (i.e. religious schools) in Pakistan with full support from the West in return to advance their strategic interests. Later on religious schools became the most potent vehicle of 
dissemination of extremist religious view and also encouraged secretarian division in Pakistani society. In fact, Saudi clerics have been acting as incubators of religious extremism and fanaticism worldwide. As foreign aid (mainly US military aid) flowed in, General Zia ignored the tasks of building an independent, self-reliant and sustainable economic growth strategy, which would have set the country on the path of modernization and long term development of the country. Also the heavy industries those were set-up during the Bhutto period were operating and benefiting General Zia. During the 1980s more than 2 million workers migrated to the Middle East, Europe and North America, provided huge amount of remittances, which helped to pay for the trade deficits (Zaidi, 1999).

During the General Zia-ul-Haq regime (1977-88) the average growth rates of manufacturing industries were around $9 \%$ per annum. However, the country did not witness a rapid rise in employment generation and also the growth in labour productivity fell in the manufacturing sector during the same period. The UNIDO report in 1990 on manufacturing summed up the situation as, "an underlying feature of industrialisation in Pakistan is the deteriorating performance of the manufacturing sector in generating new employment opportunities. Although the decade of the 1980s has been a period of relatively high growth in manufacturing value added, the growth in manufacturing employment has remained insignificant. This partly represents more an increase in capital industry that labour absorption during the period of accelerated expansion”. (UNIDO, 1990:20)

The average total GDP growth rates in Pakistan during the Zia regime were $7 \%$ annually between 1978 and 1987, which was largely due to an expansion of the construction sector and demands for consumer goods. In the 1980s, nearly 2.5 million Pakistani workers left to work abroad. Remittances have played a crucial role in the country's economy since 1979 and by the end of 1985 it provided as much as $10 \%$ of the GDP, but its role since then has diminished and currently less than $3 \%$ of the total GDP. The main reason appears for expansion of domestic demands for consumer goods due to huge increase in remittances, which reached at US\$ 3 billion in 1983 and also steadily flow of official foreign loans and grants amounting to an annual average of US\$ 1.45 billion due to Afghan war (Jalal, 1990; Siddiqui, 1989). After 1979, the Soviet Union's invasion of Afghanistan, both bilateral and multilateral aid provided substantial funds for the Pakistan's economy (Jalal, 1990). I find that the foreign aid inflows were an important source to finance industrial investment both during General Ayub and Zia period. And also in Zia's period the remittances from the expatriates did help to remove the foreign exchange deficits. However, at the same time neglected the talks of mobilization of domestic resources for investment in modern industries in Pakistan. It also gave the country false sense of temporary economic security. By the end of the 1980s the remittances exceeded the value of country's total exports. The hard currency was largely spent on buying land, building houses and on consumer durables.

General Zia-ul-Haq regime had neither a long term vision on economy nor a clear economic strategy. The military spending in real term rose by over $160 \%$ under his rule i.e. a growth more than 9\% annually. As Hasan (1998) argues that "the unprecedented growth in defence spending, on the one hand, squeezed development spending and, on the other hand, fuelled fiscal deficits...Whatever, the merits of increased defence spending, the hard choices 
between defence and development were never really debated during the General Zia period”. (Hasan, 1998: 252)

After the death of General Zia in a plane crash, Ms Benazir Bhutto was elected as Prime Minster in 1988. Soon after coming to power Ms Bhutto launched neo-liberal reforms also known as structural adjustment programmes under the supervision of IMF and the World Bank (Note 16). This also meant the government was unable to use fiscal and monetary policies to stimulate the economy. Their main concern was fiscal deficit and was asked to lower its deficit to $4 \%$ of the GDP. It was supposed to be achieved with the help to increase indirect taxes and decrease in public spending. For instance, the public spending in the area of development was 9.3 of GDP in 1986, but it declined to less than $3 \%$ by 2004 (World Bank, 2006; Zaidi, 2005).

Another area of neo-liberal reforms was a reduction in import tariff rates, which was reduced from $125 \%$ in 1992 to $25 \%$ in 2004 (World Bank, 2006). As a result, a large number of domestic industries were closed down, as they were unable to compete with cheap imported goods. This resulted in loss of jobs and decline of tax revenue for the government. I mean to say that on the name of 'openness' and 'competition' the economy was opened for foreign businesses, without providing any protection to domestic producers, which resulted in closure of business units and rise in unemployment. At the same time, the prices of utilities such as gas, electricity and petroleum products were repeatedly increased.

Afterwards, once Nawaz Sharif became the Prime Minister of Pakistan, he too carried out IMF's led Structural Adjustment Programme and the role of state in the provisions of social and infrastructural facilities was further reduced remarkably under the wave of denationalization and privatization. The public owned industries were handed over to the private sector. A large-scale privatization was carried out in the 1990 under Nawaz Sharif's government. Disinvestment and de-regulation committee was formed to identify the industries to be privatized. The main reason seems to be the need to raise revenue. During this period a number of heavy industries were privatized. The researchers have found that the privatization process was mismanaged and ill prepared. As summarized by Institute of Developing Economics Study (1994), “The privatization process was severely criticised by several quarters for the lack of transparency, and the inadequate attention paid to the antecedents of the new management. It was suggested that the bid evaluation procedures were incorrect and furthermore, inconsistently applied from case to case. It was also alleged that the process suffered from favouritism, as some bidders had privileged access to information and competing bids”. (Institute of Developing Economics, 1994: 324)

Following the decision to carry out a nuclear test in 1998 by Prime Minister Nawaz Sharif, the Western governments imposed economic sanctions and IMF also withdrew any aid to Pakistan. As a result, the country faced serious balance of payment crisis. The depositors in panic started withdrawing their deposits, which led to huge capital flight and depletion of reserves. Its exports were stagnant around US\$ 8 billion in during the second half of the 1990s and remittances also did not rise as witnessed earlier in 1980s. In 1997 Pakistan had witnessed a massive foreign debt, where the debt was in excess of $100 \%$ of GDP. Debt 
servicing was taking away revenue from developmental and social expenditure projects.

Pakistan was in deep economic crisis when General Musharraf took over in a military coup in October 1999. Soon after taking over General Parveez Musharraf appointed Shaukat Aziz, who was then (a senior manager of the Citibank, as finance minister in 1999). Aziz was promoted as prime minister in 2004 and he was given the task to stabilize the macroeconomic situation. His policies of deflating the economy to control inflation and domestic demands resulted in dramatic decline in growth rates to just $2 \%$ in 1999. The government cut down the developmental and educational expenditure, leading towards further fall in growth rates $1.9 \%$ in 2001. Shaukat Aziz in order to tackle the balance of payment crisis a number of state owned enterprises such as banks, telecommunications and power were sold into private hands. While at the same time several economists from the IMF and the World Bank were brought to Pakistan e.g. the key among them was Ishrat Husain, who was appointed as the governor of the State Bank of Pakistan.

After the $11^{\text {th }}$ September 2001 attack on World Trade Centre and soon after the US invasion of Afghanistan, once again Pakistan became a strategic allies in the war. The economic and military aid again started flowing-in and soon after the IMF approved new aid i.e. $\$ 1.5$ billion and also previous debts were rescheduled to Pakistan. Moreover, the US support to control illegal flow of funds (also known as hawala) and closer supervision of banks led to larger amount of remittances being sent through legal banking system. Due to this, the legal money transfer rose sharply from $\$ 1$ billion in 1999 to $\$ 4.2$ billion in 2003. The rise in foreign aid, the transfer of payment, along with the exports provided short-term boost to the economy and the country witnessed a current account surplus. However, upswing in the economy did not last very long and in 2005 again economy began to slow down and price of consumers goods rose and also the current account deficit. All these difficulties were not government's making, but partially due to poor domestic food grain production and also sharp rise in global food and petroleum prices. In fact, many other developing countries experienced similar situation, but proved to better prepared, while Pakistan government failed to show any viable strategy to resolve the crisis. The trade deficit rose to high levels to US\$ 15 billion in 2008 from \$10 billion in 2007. Foreign exchange reserve plunged low levels to $\$ 8.5$ billion in 2008 from $\$ 13.5$ billion in 2007. Since 2005 prices were rising at the rate of $12 \%$ annually and the inflation further rose to $22 \%$ in 2008-2009. In 2007 the poor harvest and higher import prices, especially food exacerbated overall price rise. The deteriorating living conditions of the people coincided also the conflict with judiciary and opposition political parties. It became increasingly clear that the so-called turnaround in 2001 failed to address the long-term structural weaknesses.

Shaukat Aziz continued to implement the neo-liberal economic reforms. As a consequence, inequality increased further. The wealth acquired by the rich decided to invest in shares and properties for quick profits. As a result, the share prices and urban property went up along with multilateral and bilateral aid, which was claimed as a success story. But these so-called high growth rates have by passed the majority of the people who saw their living conditions deteriorated due to rising unemployment, high inflation and corruption, which led further disenchantment with the military regime. 
Khan's (2007) study regarding the nine years of Musharraf regime, find that there was an increase of 2 percentage points in the unemployment rate while real wages of both skilled and un-skilled declined by 4 to $9 \%$ despite the share and bond market boom. The macroeconomic stability was achieved by cuts in development spending and wages. The number of people living below poverty line was sharply increased, despite the inflows of massive foreign aid and the World Bank led anti-poverty reduction programme. Under General Musharraf (1999-2008) corruption and nepotism became more widespread and inequality and unemployment increased further.

Pakistan's macroeconomic indicators show that inflation has risen since 2004. For instance, the prices rose $7.4 \%$ 2004, which increased to very high levels i.e. $20.2 \%$ in 2008 and declined to $13.9 \%$ in 2009 (see Table 8). Literacy rate is quite low i.e. $59.8 \%$ (see Table 8).

Table 8. Pakistan Statistical Summary

\begin{tabular}{|l|l|l|l|l|l|l|}
\hline & 2004 & 2005 & 2006 & 2007 & 2008 & 2009 \\
\hline Inflation (\% change) & 7.4 & 9.1 & 7.9 & 7.6 & 20.2 & 13.9 \\
\hline Birth rate (per ’000) & 31.2 & 30.9 & 30.6 & 30.4 & 30.1 & 29.8 \\
\hline Total exports (US\$ billions) & 13.34 & 16.03 & 16.93 & 17.84 & 20.48 & 17.53 \\
\hline Total imports (US\$ billions) & 17.9 & 25.33 & 29.82 & 32.59 & 42.14 & 31.7 \\
\hline $\begin{array}{l}\text { Infant mortality (deaths per '000 live } \\
\text { birth) }\end{array}$ & 71.1 & 69.5 & 68.2 & 66.9 & 64.6 & 63.6 \\
\hline Adult literacy & 49.4 & 49.9 & 54.2 & 54.9 & 57.7 & 59.8 \\
\hline
\end{tabular}

Source: Pakistan's Economic Survey, various years, Government of Pakistan, Ministry of Finance, Islamabad: Printing Corporation of Pakistan.

Pakistan is the only country to have approached the IMF more than 15 times and received numerous bailouts from the World Bank since 1988. However, the poverty has risen sharply during this period and the overall economy shows to have failed on many counts. Since 1988, the IMF has been involved in formulating and advising the economic policy in Pakistan.

Pakistan's failure to lay the foundation of long-term sustainable and self-reliance growth is the main challenges the country is facing. Mr. Gilani, who became Prime Minister in 2008, has simply continued the neo-liberal economic policies, which were adopted since 1988 on the advice of IMF and World Bank. The constraints appears to be poor human resources and low levels of skills leading towards declining competitiveness in the country's traditional export sectors like textiles and leather. Any radical change requires government intervention to enhance competitiveness in export sectors and improve levels of skills to boost productivity. However, given the active role of the IMF, which is against of any state intervention, seems to be long way.

The macroeconomic instability lowered the foreign investors' confidence and the FDI experienced \$ 5 billion in 2004 to less than \$2 billion in 2007. Prime Minister Gilani sought assistance of $\$ 15$ billion from IMF in 2008. Since 2008 the deepening economic crisis such as high inflation, depleting foreign exchange, deteriorating balance of payments and declining the value of Pakistani Rupees has been witnessed. The new government led by 
Prime Minister Gilani is unable to resolve the economic problem the country experiences, despite the large amount of aid from IMF, the US, Saudi Arabia and Gulf States. However, most observers have overlooked the close relationship between the western countries, international financial institutions and the ruling elites in Pakistan and the how these relationships has shaped the country's economic policies. For instance, most of the major economic changes such as denationalization of industries and banks during the Zia period have been agreed by the IMF. The country provides very clear example of the limitations of the IMF prescriptions and its adverse impact on the common people.

The crucial differences between Pakistan and East Asia was that successful East Asian economies carried out land reforms, which besides reducing rural inequalities, also expanded domestic markets for consumer goods (Note 17). They also under took various public funded programmes such as rural development and literacy rates in order to raise productivity in the agricultural sector and also to raise the incomes of the rural poor and middle farmers. On the other hand the rural reforms in general and land reform in particular were largely cosmetic in Pakistan (Zaidi, 2005).

Table 9 shows that GDP growth rates were higher in the 1960 i.e. $6.7 \%$ average per year. However, it declined in the 1990s to 4.6 and continued to $4.3 \%$ in 2003. Manufacturing sector declined from $9.9 \%$ in 1960 to $4.8 \%$ in 2003. Services did not do any better i.e. $6.7 \%$ in 1960 to $4.5 \%$ in 2003. During the 2008 and 2009 the GDP growth rates declined to $3.1 \%$ and $2.7 \%$ respectively. In year 2009 , the growth rate was only $2.7 \%$, which is lower than rate of population growth (see Table 9).

Table 9. Average Annual Growth Rates in various sectors in Pakistan (in \%)

\begin{tabular}{|l|l|l|l|l|l|l|l|l|}
\hline & $1960-69$ & $1970-79$ & $1980-89$ & $1990-99$ & $2000-2003$ & $2004-2007$ & 2008 & 2009 \\
\hline GDP & 6.7 & 4.8 & 6.4 & 4.6 & 4.3 & 5.6 & 3.1 & 2.7 \\
\hline Agriculture & 5.0 & 2.3 & 5.4 & 4.4 & 3.7 & 4.1 & 3.6 & 2.5 \\
\hline Manufacturing & 9.9 & 5.5 & 8.2 & 4.8 & 4.8 & 5.8 & 3.6 & 2.8 \\
\hline Service sector & 6.7 & 6.2 & 6.6 & 4.6 & 4.5 & 6.5 & 4.1 & 2.9 \\
\hline
\end{tabular}

Source: Pakistan Economic Survey, various years, Islamabad: Government of Pakistan; and also World Development Indicators, World Bank, 2010.

The service sector experienced an impressive growth, including construction sector. Its share in total non-agriculture employment rose from $20 \% 1969$ to $33 \%$ in 1998. Contrary to this, the share in manufacturing in total non-agricultural employment has declined from $39 \%$ to $16 \%$ during the same period. By 2003, the economic structure has changed and agriculture sector's contribution has decreased i.e. contributes merely $24 \%$ towards GDP, while manufacturing is $25 \%$. Contrary to this, the service sector contribution has risen and it contributes more than half of total GDP. While in terms of employment agriculture is the biggest sector and provides jobs to around $48 \%$ of the total labour force.

During the 1997-98 the debt servicing and military spending together exceeded total annual revenue of the government, which led to increased borrowings and cut down in development programmes. The country's financial imbalances are startling. In 2001 debt and defence 
amounted to more than two-thirds of the total public spending, i.e. US\$ 4.2 billion on debt and interest repayment and US\$ 2.5 billion on defence, compared to tax revenues of US\$ 6.9 billion. The IMF came to rescue package also know as Structural Adjustment Programmes, included de-regulation, re-sale of public assets, further rise in indirect taxes, reduction in import duties and devaluation of Pakistani Rupees. As a result real wages declined and with fiscal spending cuts joblessness rose to new heights. The devaluation of Rupees could not boost exports, as IMF was expecting, while the lowering of import duties further deteriorated balance of payments situation. Devaluation also causes foreign-currency debt to swell in domestic currency.

\section{Deepening Crisis and Poverty in Pakistan}

Industrialisation was seen as a means to eliminate poverty, create employment and to combat illiteracy and disease, the legacies of colonial past. Pakistan economy at the eve of independence inherited an economy, where exports of raw materials such as cotton, leather etc. were prevalent, unlike India where British capital investment had created some pockets of industrialisation. In Pakistan to establish modern industries were quiet problematic as there was more or less complete absence of any indigenous capitalist class to accomplish it. There were few small production units that did exist but their owners were Hindus, who migrated to India during the partition. Therefore, as Alavi argues, "the initiative and drive for building industrial capital came from the state”. (Alavi, 1983: 47)

Pakistan has pursued protectionist trade policies i.e. to protect its nascent industries against foreign producers since early 1950s. The industries enjoyed high levels of tariff protection. According to mainstream economists these policies led to wasteful use of resources and inefficiency in resource use. This has been one of the factors in slow growth of output that has led to high levels of poverty in Pakistan (Easterly, 2001).

However, Pakistan adopted trade liberalization since 1988 by reducing the rate of tariff and import restriction. It was claimed that the move towards lesser trade restrictions would increase returns to the factor of production such as labour. For instance, the Stopler-Samuelson theorem of price equalisation argue that the wage and income differentials due to existing factor endowments differentials tend to disappear over time after trade liberalization. It was said that trade liberalization and tariff reduction would help improve living conditions and will be able to reduce poverty in Pakistan. However, in reality it did not happen and poverty and inequality increased over time (Gardezi, 1998).

The concentration of land in the hands of small proportion of the rural population appears to be the main cause for the impoverishment of the rural poor because they do not own the vital assets (Note 18). This opens up the vast possibilities for their exploitation, misery and abuse. The unequal power that derives from the unequal landownership is the reason behind the continuing injustices in the rural areas (Hussain, 1988). Although in Pakistan land reforms legislation were passed in 1959, 1972, and in 1977, the impact of these land reforms has been negligible as far as the land concentration is concerned. Under the cosmetic land reform provisions landlordism became more established and entrenched. In rural areas, the access to land is considered as major avenues for social status and most of the key activities are related 
directly or indirectly to the agriculture sector. In agrarian societies land besides being primary asset, also is expression of economic, social and political power. The large concentration of landownership is being regarded as prime obstacles to sustained growth and economic development (Note 19). Therefore, demand for radical land reforms is seen as crucial on the grounds of social justice as well as a pre-requisite for economic development (Hussain, 1988).

However, in the late 1960s and early 1970s the 'Green revolution' (Note 20) was launched with full support from the US and it was claimed that it would remove rural poverty and injustice. The key variables for the success of the 'Green revolution' technology package were new seeds, chemical fertilizers and irrigation to increase the total output of agricultural commodities. The rural rich constituted less than $5 \%$ of the rural population, who were the principal beneficiaries of the Green Revolution. As Hussain notes, "The new technology made it possible to accelerate agricultural growth substantially through an 'elite farmer strategy', which concentrated the new inputs on large farms. Now the crucial determinant in yield differences became not the labour input per acre in which small farms had been at advantage, but the application of the seed-water-fertilizer package over which the large farmers with their greater financial power had superior access. Thus, the technocrats felt that the Green Revolution had made it possible to accelerate agricultural growth without having to bring about any real change in the rural power structure”. (Hussain, 1988:178)

No doubt that feudalism in rural Pakistan has gone through a number of dynamic changes which are affecting the shape of rural society such as family subdivisions of land holdings. However, the landlords still exercise considerable influence and they have diversified their assets in urban property, businesses, sugar mills etc. In fact, establishment of modern industries failed to achieve a self-reliance and promote domestic economy mainly the presence of extreme inequality of income distribution restricted domestic markets, as the rich opted for imported goods. In Pakistan, the utter neglect of increase in productivity of the workers through training and education to the possibility of moving from the production of simple consumer durables towards the production of more sophisticated consumers and high tech capital goods, which could be sold to the Western markets. As such successful transformation did happen to countries of East Asia such as Japan, South Korea, Singapore, Taiwan etc (Siddiqui, 2010a).

The researchers have found that poverty, inequality and unemployment have increased since 1988 with the adoption of neo-liberal economic reforms and the country has also witnessed high inflation and slower GDP growth (Zaidi, 2005). The reason for implementing such disastrous policies and seeking continued IMF assistance due to the fact that the ruling elites are unwilling to carry out essential economic reforms in order to address the main problems of the economy. They find it easier to borrow and maintain status quo. In the absence of radical land reforms, progressive taxation on the large landholders and cutting down the military and non-developmental excessive expenditure, the economic crisis will deepen further. The neo-liberal (pro-market) reforms has increased burden for the working people, by insisting on a reduction in food subsidies and also withdrawal of all inputs subsidies into agriculture. 
Nearly $60 \%$ of the population lives in rural areas, out of which $35 \%$ lives below the poverty lines. The incidence of rural poverty is highest among those who own no land and more than half of the landless labourers are poor. It clearly indicates that rural poverty has a critical link with landownership and access to land. Therefore, land reform is vital for reducing poverty and inequality in rural area.

Remittances declined significantly from US\$ 2.9 billion in 1983 to 1 billion in 1999. 1983 was peak in terms of inflow of remittances, at $10.1 \%$ of GDP; they financed $96.6 \%$ of the trade deficit and $84.8 \%$ of the current account balance. Since the 1990 remittances started to decline and it led to a rapid depletion of financial reserve.

Rich Pakistanis have accumulated wealth but they are very few and operate as junior partner to metropolitan capitalism. Much of the wealth of the country have been transferred to overseas bank accounts or invested abroad, which was exacerbated since the policy of de-regulation and privatisation was adopted in the country, which did away with domestic capital control on the advice of World Bank and IMF. They always relied heavily on state support and protection to accumulate, thus were unable to develop independently and stand together as a class. The heavy reliance of state support and subsidies and tax concessions has created endemic system of bribes and nepotism to enrich both bourgeoisies and civil servants. Moreover, having accumulated wealth through the nexus of corruption, many former civil servants and the military officials have set-up businesses directly or through their relatives. As Jalal notes, "The defence trust and foundations run by the army has eight manufacturing units, including sugar, fertilizers, cereals, liquid gas, metals and a gas field as well as transportation companies, schools, hospitals etc.”. (Jalal, 1995: 143)

\section{Long terms Structural Constraints}

In order to understand the Pakistan's recurrent macroeconomic imbalances and the constraints they impose to carry out radical change for the benefit of the vast majority of the people. It will be crucial to analyse the structure of the economy and compare with India. The structure of the economy is very similar. For example, in the agricultural sector output has declined to about 22\% of the GDP, the industrial sectors in both countries are around $27 \%$, while the service sector is both countries is above $50 \%$. However, the similarities do not reveal the vital structural differences in these two economies (Khanna, 2010).

In Pakistan agriculture is the largest part of the economy, employing $44.2 \%$ of the work force. A large gap exists between the potential and realized yield for almost all the major crops. The country is the world's fourth largest producer of cotton but output will drop by about $15 \%$ in 2010 owing to Pakistan's severe flooding. An estimated $80 \%$ of cotton fields in some areas have been damaged. Industrial growth has slowed compared to recent years owing to a fall in demand for textiles and problems in that industry. The textile industry suffers from power shortages, reduced availability of cotton and lack of competitiveness (Zaidi, 2005).

The country has failed to change the structure of industrial output and its export. Pakistan's export share in the GDP has been stagnant for the last 25 years. For example, textiles, leather, export goods etc. constitute about $80 \%$ of the total export, which is low technology and low 
value added products. It has got small and declining, which has failed to penetrate in foreign markets, given its narrow and mostly agricultural based export items. The country's textile industries have lost prominent position of the 1970s and currently hold about $2 \%$ of the world market (Kibria, 1999). It seems that the government has failed to take initiative of industrial upgrading, which could have played an important role in creating jobs in expanding export sectors. The positive role that state intervention could play in promoting industrial upgrading and furthermore, a co-ordination is needed across the different input markets such as finance, legal institutions, infrastructure and education. I mean state intervention is required to facilitate the supply of necessary resources, which successive governments in Pakistan have miserably failed to provide.

The Table 10 shows that during the last two decades, the structure of the exports has not changed and cotton is still contributing nearly two-third of the total exports. Agricultural commodities still are the country's major export items and the country has failed to move towards high value commodities (see Table 10).

Table 10. Pakistan's structure of exports (\% of total)

\begin{tabular}{|l|l|l|l|l|l|}
\hline Commodity & $1990-91$ & $1994-95$ & $1999-2000$ & $2004-05$ & $2007-08$ \\
\hline Cotton & 61.0 & 58.7 & 61.0 & 57.4 & 61.5 \\
\hline Leather & 9.1 & 8.0 & 6.3 & 5.8 & 4.5 \\
\hline Rice & 5.6 & 5.6 & 6.3 & 6.5 & 6.6 \\
\hline Synthetic Textile & 5.7 & 7.1 & 5.3 & 2.1 & 3.0 \\
\hline Sport goods & 2.2 & 3.2 & 3.3 & 2.1 & 1.6 \\
\hline Sub-total & 83.6 & 82.6 & 82.2 & 73.9 & 77.2 \\
\hline Others & 10.7 & 12.9 & 17.8 & 26.1 & 22.8 \\
\hline Total & 100 & 100 & 100 & 100 & 100 \\
\hline Total exports (\$ millions) & 6,131 & 7,759 & 8,190 & 14,482 & 20,122 \\
\hline
\end{tabular}

Source: Pakistan's Economic Survey, various years, Government of Pakistan, Ministry of Finance, Islamabad: Printing Corporation of Pakistan.

The argument in support of devaluation is that it would make export cheaper in the international market and ultimately export would increase. The experience of successive devaluation shows that exports have increased in volume and value terms but the increase was small compared to the fall in value of the Pakistani Rupee. The reason appears to be most of the country's export seems to be textile, which faces quotas. At the same time prices of imports increased leading to further trade imbalances. For instance, Ishrat Husain finds that, "Pakistan has devalued its currency several times but the impact on export expansion has been minimal”. (Husain 1999: 173)

An important point of the neo-liberal reforms is to extend the role of the market and reduce the role of the state in the economic affairs. It is based on the assumption that the market is always right. 'Getting price right' i.e. having prices as close as possible to what a free market would determine. Patnaik argues that (1994) "Getting prices right as a condition for becoming a successful exporter, and for achieving high rates of viable growth, is belied consistently by actual experience. Virtually every instance of noticeable export dynamism, 
whether it is Germany in the late $19^{\text {th }}$ century, or Japan and South Korea in the post-war period, has been characterised not only not getting prices right in the neo-classical sense, but by having differential prices for the same commodity between the domestic and foreign markets. Indeed such differential prices are what precisely have helped the export drive: capitalists have made up through profitable domestic sales they have lost in foreign markets by keeping prices low for the sake of export expansion”. (Patnaik, 1994: 684)

Felipe and Lim (2008) argue that constraints on development and state inability to tackle the balance of payment crisis, is mainly due to low public expenditure, especially developmental and social expenditures. The recurrent of balance of payment crisis, which was managed repeatedly by cutting spending on development, has prevented investment in the areas where private sectors has been unwilling to invest. In order to modernize and increase competitiveness of the economy, it is considered vital. Moreover, the total neglect of heavy industries, which was briefly prioritize during the Zulfikar Ali Bhutto period, has undermined its ability to change the structure of production from low value towards high value production, as some south-east Asian economies e.g. Malaysia has done successfully more recently.

The government was unable to mobilize resources. For example, the total tax revenue to GDP declined from about $12 \%$ in 1999 to average $10 \%$ of the GDP. While at the same time military spending has been higher than developmental expenditure for the last nearly 3 decades. Moreover, the military and debt repayment has taken away nearly $60 \%$ of the total revenue for the last ten years (Khanna, 2010).

Table 11. Output Structure - selected south Asian countries, (\% Of GDP at current factor cost).

\begin{tabular}{|l|l|l|l|}
\hline Country & 1990 & 2000 & 2007 \\
\hline Pakistan & & & \\
Agriculture & 26.0 & 25.9 & 19.6 \\
Industry & 25.2 & 23.3 & 26.8 \\
Services & 48.8 & 50.7 & 53.7 \\
\hline India & & & \\
Agriculture & 29.3 & 23.4 & 17.6 \\
Industry & 26.9 & 26.2 & 29.4 \\
Services & 43.8 & 50.5 & 52.9 \\
\hline Sri Lanka & & & \\
Agriculture & 24.2 & 15.6 & 11.7 \\
Industry & 28.9 & 27.8 & 29.9 \\
Services & 46.9 & 56.6 & 58.4 \\
\hline Bangladesh & & & \\
Agriculture & 30.2 & 25.5 & 18.9 \\
Industry & 21.5 & 25.3 & 28.5 \\
Services & 48.3 & 49.2 & 52.6 \\
\hline
\end{tabular}

Source: Asian Development Bank, key indicators, 2008, Manila.

The output structures of few selected south Asian countries are shown in the Table 11 for the 
last two decades. The changes across the various sectors are similar among these countries (see Table 11). For instance, in all countries the contribution of the agriculture to the total GDP has declined over the years.

The data on the savings and investments indicates wide differences among the south Asian countries (see Table 12). For example, Pakistan's domestic savings has increased very little i.e. $13.5 \%$ of the GDP in 1990 to $14.7 \%$ of the GDP in 2007, while India's rose from 22.8 to $34.8 \%$ of the GDP in 2007. Moreover, India has grown largely on domestic savings and investment, while Pakistan has financed its investment from the foreign savings, aid and loans. Its economy is characterised by very low domestic savings of about $15 \%$ of the GDP (see Table 12). Another major difference is that Pakistan's export items are very few and low value products. Pakistan has hardly got any basic industries and has very small capital goods sector. Despite its military cooperation with the west, Pakistan was unsuccessful in penetrating in services and outsourcing activities, as India and other emerging economies has done it.

Table 12. Savings and Investment - selected south Asian countries, (\% 0f GDP at current market prices).

\begin{tabular}{|l|l|l|l|}
\hline Country & 1990 & 2000 & 2007 \\
\hline Pakistan & & & \\
Gross domestic saving & 13.5 & 16.0 & 14.7 \\
Gross national saving & 24.7 & 20.1 & 24.0 \\
Gross domestic capital formation & 18.9 & 17.2 & 23.0 \\
\hline India & & & \\
Gross domestic saving & 22.8 & 23.7 & 34.8 \\
Gross national saving & 22.2 & 25.5 & 37.1 \\
Gross domestic capital formation & 26.0 & 24.3 & 38.4 \\
\hline Sri Lanka & & & \\
Gross domestic saving & 12.0 & 15.2 & 16.9 \\
Gross national saving & 14.3 & 19.1 & 22.7 \\
Gross domestic capital formation & 20.7 & 25.4 & 27.2 \\
\hline Bangladesh & & & \\
Gross domestic saving & 12.9 & 17.9 & 20.5 \\
Gross national saving & 17.1 & 23.1 & 29.1 \\
Gross domestic capital formation & 17.1 & 23.0 & 24.3 \\
\hline
\end{tabular}

Source: Asian Development Bank, key indicators, 2008, Manila.

With the increase in external imbalances the government opted for IMF led Structural Adjustment Programmes in 1988. The SAP was supposed to restore macroeconomic balances. The government took several measures to reduce budget deficits such as wage restraints, freezing employment in public sector and limiting discretionary grants to provinces. The budget was reduced from $8.5 \%$ of the GDP in 1988 to $6.5 \%$ in 1990. However, in 1991 a sharp fall in the public revenues (Note 21) resulted in an increase in fiscal deficits to $8.7 \%$ of the GDP. The government spending on social services mainly on education and health, which 
was already lowest compared to other south Asian countries, declined further as a percentage of GDP from 3.4 \% in 1988 to 2.8 in 1991 (Anwar, 1996). The literacy rate in Pakistan is one of the lowest in South Asia and is worse than countries which have per capita GNP close to Pakistan level. Moreover, there is a marked regional difference. For example, the literacy rate overall was $55 \%$ in Sindh but was only $8.2 \%$ in Baluchistan. Total government spending on health and education measured as percent of GDP remained constant even declined slightly. Hussain (1999) argues that the ruling elites found it convenient to perpetuate low literacy rates. The existence of a large proportion of illiterate people would simply mean the lower probability that the ruling elite could be displaced. Overall the public sector investment has declined from $12.4 \%$ of GDP in 1977 to $6.9 \%$ of GDP in 1997. As a result of the SAP economic reforms, the real wages in agriculture and manufacturing sectors declined in the beginning the 1990s and it had negative impact on the income distribution. For instance, the share of wages in national income declined from $32.3 \%$ in 1988 to 30 \% in 1991.

Pakistan started to liberalise the trade regime and lowered the maximum tariff from $225 \%$ in 1988 to $100 \%$ by 1990, as a result the supply of imported consumer goods rose sharply (Pakistan's Economic Survey, 1993; Anwar, 1996:917). The reduction in tariffs led to the shift in domestic demand from local goods to import goods, as a result overall contraction took place in economic activity. Trade liberalization resulted in rise of rise unemployment in the early 1990s. The combined impact of public spending cuts and trade liberalization adversely affected the unemployment situation and in the urban unemployment increased from $4.5 \%$ in 1988 to $8.2 \%$ in 1991 (Anwar, 1996:918).

Since the late 1980s, the evolution Pakistan's economy is closely linked with the international financial institutions and the western countries strategic interests, especially the United States. As a result, the economy has moved into dependent development, which appears to be an important reason for the on-going economic crisis and any attempt to build self-reliant development is sidelined. The structural economic weaknesses are associated with the structure of production, items of exports and skills and education levels of the working people and the nature of the country's economic integration with the global economy. Ali argues that, "Throughout the 1990s, the IMF had scolded civilian governments for failing to keep their restructuring promises. Musharraf's regime, by contrast, won admiring praise from 1999 onward for sticking to IMF guidelines "despite the hardship imposed on the public by austerity measures”. Improvement and desperation in the burgeoning city slums and the countryside - still home to $67.5 \%$ of the population - were exacerbated further. Some 56 million Pakistanis, nearly $30 \%$ of the population, now live below the poverty line; the number has increased by 15 million since Musharraf seized power”. (Ali, 2008:256)

\section{Conclusion}

The study finds that capitalism has failed to remove poverty and inequality despite its long history of penetration in South Asia under colonial and neo-colonial regimes and in spite of being backed by the new technology and increased amounts of credits. The experience of Pakistan clearly illustrated this fact. It is not simply question of growth rates. There is also a lack of discussion about the presence of a large proportion of people living in sub-human 
conditions and lack of overall and holistic development of human being.

It is true that the Indian economy has grown 5-6 \% annually during the last two decades. This is considerably higher than achieved in the preceding years, which only averaged $3.6 \%$ per year. However, the service sector, which witnessed a rapid economic growth since the neo-liberal reforms began, accounts for a much smaller share in employment relative to their contribution to GDP. This means that a large proportion of those employed are concentrated in the slow growing and low productive sectors in the Indian economy. Since 1991 with the adoption of neo-liberal economic reforms the growth rates have risen along with the process of accelerated liberalisation of trade and capital market, but failed to bring any dramatic change in generating employment. This period was also marked by very slow growth in job creation, especially in rural areas. Globalisation has affected India in various ways such as greater reliance on export particularly of services and increased dependence on capital inflows especially of the short-term. The sluggish investment in corporate sector, especially in manufacturing/productive capital indicates the declining importance of this sector compare to financial sector and speculative activities in stocks has grown sharply since 2000.

India's euphoria with the high growth rates of two decades, has given the ruling elites super power ambitions. The super rich in India currently have an important voice in the formulation of government policies. They ignore the fact that more than one-third of the population live in absolute poverty and the appalling conditions of the country's health sector, which is worse than some sub-Saharan African countries. For example, at present the percentage of underweight children in India is five times that in China. India has long witnessed extensive poverty coexistence with rapid growth that increases in output by following either the ISI or neo-liberal economic polices.

The government is doing everything to keep the economy attractive for international capital and also "credit worthy", which means to offer higher interest rates than the developed countries. A fiscal deficit has to be kept down in order to not scare away foreign investors. It means reversing the neo-liberal economic polices.

Our study also find that despite more than two decades of rapid GDP growth rates, the Indian economy has failed to improve the living conditions for the majority of the population. Therefore, an alternative strategy should be based on increased emphasis on wage-led growth financed by fiscal and monetary measures that would ultimately stimulate the expansion of production for mass consumption for domestic markets. The growth process in economy like India, therefore need to be agriculture and manufacture-led, rather than services. The manufacturing sector needs to increase its share of the GDP both in terms of income and employment to provide jobs. Then it is obvious that the agriculture sector needs higher public investment and better availability of credits from financial institutions. Also the implementation of land reforms will counter landlessness. This will generate more employment and will improve consumption levels of the rural poor.

Pakistan has had a respectable per capita growth between 1950 and 2000, and has a well educated urban population. But still the country underperforms on the most social indicators such as education, health, sanitation, gender equality etc. The country has witnessed intensive 
involvement by donors and international agencies and received US\$ 58 billion in foreign aid in the above period. Pakistan is the third largest recipient of official development assistance in the world over 1960 and 2010. Pakistan's experience of receiving US aid during the last six decades clearly shows that it did not benefit the majority of the people. Moreover, the United States military and economic aid has not helped the country to move towards economically self-reliant and independent. I find such aid is strengthening military and other authoritarian forces against the working people.

Once Pakistan adopted the Structural Adjustment Programmes, private capital took over from the state as leading role in developmental activities. Private investment was supposed to increase, but it did not happen and the economy experienced a slowdown. Most of the finance ministers since 1990 have had a stint in the IMF and World Bank's office and broadly toed with the line charted by the these two Western institutions. Moreover, as Pakistani dependence on foreign loans increased, there was little effort by the government to broaden the industrial base to encourage diversification of its exports. At the same time, with the adoption of neo-liberal economic reforms imports rose, largely financed through the foreign borrowings. As a consequence, balance of payments crisis has deepened and the ruling elites have no interests in finding long term solutions to the current deepening socio-economic crisis. Though the growth rates picked up for short period after 2000, but it impaired the country's long-term capacity to mobilise domestic resources for long term investments and achieve sustainable and equitable development. As a consequence, the country ranks at the bottom of the United Nations Development Programme on human development. Its reliance on external resources has risen sharply since 1980s and at present half of the external assistance goes to meet the debt burden. Moreover, the foreign debts have risen quite sharply with the last ten years.

There are large numbers of evidence to show that since the adoption of the neo-liberal reforms in 1988 did not reduce poverty and inequality in Pakistan. There has been not only an increase in the number of people living below the poverty line, but also a decline in growth rates, worsening balance of payments situations and rising unemployment and inequality. From the beginning in order to develop capitalism there were number of hurdles to this tasks. In the absence of comprehensive land reforms (i.e. removal of absentee landowners, tenancy and land ceiling reforms) wide inequality prevailed in rural areas, which add further constraints to the expansion of domestic markets. The failure to break the monopoly of landownership from the rural elites is the root cause in the continuing atrocities against the vulnerable sections of rural inhabitants. Moreover, this proved to be a major constraint against the expansion of rural middle classes .Thus, the existence of large landowners did put hurdles to increasing agriculture output and incomes of the small farmers and tenants. As agriculture surplus remained in the small proportion of rural elites, which further narrowed the markets towards luxury goods rather than investments in capital goods sectors to improve the overall productivity of the manufacturing sectors to improve competitiveness.

In Pakistan, the average GDP growth rates declined in 1990s, compared to the 1980s by one-third. The growth rates of manufacturing sector went down from $8.2 \%$ to $4.8 \%$ annually for the same period. While crony capitalism flourished, local industries that were once the 
backbone of the economy were left to decline. Pakistan export is based on primary commodities, with a heavy dependence on cotton and textile industry and neo-liberal economic reforms since 1988 did not alter the situation. Pakistan has failed to change the structure of industrial output and its export. The share of export in the GDP has been stagnant for the last 25 years. For example, textiles, leather, export goods etc. constitute about $80 \%$ of the total export, which is low technology and low value added products. It has got small and declining export items, which has failed to penetrate in foreign markets, given its narrow and mostly agricultural. Therefore, industries need to be modernized in order to become competitive, all these tasks state active intervention is required, which neo-liberalism is reluctant to support. I find that the successive governments have neglected the industrial upgrading, which is necessary for the economic development, and thus failed to diversify economic activities and build a successful manufacturing sector.

Pakistan presents a development paradox. The country has experienced high economic growth rates for large part of the past sixty years, yet its social sector development is abysmal. It seems a paradox i.e. Pakistan has achieved relatively high growth rates but without adequate provision for the social sector. The economic growth has not trickled down in the form of increased social development. For instance, the government boosted the high GDP growth rates of average 6 \% per annum between 1956 and 1990 as one among the top among the South Asian countries (Pakistan Economic Survey, 1996, xi), while on the other hand UNDP's Human Development Report in terms of overall development and human welfare presented Pakistan at the bottom of the list (Noman, 1997). According to official statistics, the percentage of households living in absolute poverty has risen from $21.4 \%$ in 1991 to $30.6 \%$ in 2008. Moreover, nearly 60 million people i.e. $30 \%$ of the population now live below officially defined poverty line, with in the last ten years it has increased by 15 million. Public spending on education in Pakistan is one of the lowest in South Asia. According to official figures, $70 \%$ of female and $41 \%$ male are illiterate. More investment in education leading towards higher literacy rates would have positive impact on productivity both in agriculture and industries. Therefore, the government should make a clear strategy to enhance equity improving public delivery of health and education, land reform and through restructuring of the credit markets to encourage the availability of credits to small farmers and small enterprises. Land reform is required to remove rural inequalities, especially economic and political power in the rural areas. In order to reduce the rural poverty, government spending has to increase in agriculture along with subsidies to the small and marginal farmers.

It seems to me that the prolonged agriculture crisis in India and Pakistan has been largely due to inappropriate government polices includes neo-liberal economic policies followed for two decades. One major factor has been the lack of government spending in agriculture sector. In both south Asian countries, the government subsidies to new inputs have been either withdrawn or sharply reduced and thus adding costs of cultivation, which needs to be reversed. In order to bring rapid economic development and to reduce political and economic power of the rural elites, the land inequality should also be addressed. 


\section{Acknowledgement}

A short version of this paper was presented at the conference organized by IPP at University of Leeds on $29^{\text {th }}$ October 2010. The author would like to thank for the feedback received from the participants, especially from Dr. Hugo Radice, Dr. Stuart Shields and Dr. John Smith. The author is grateful to Dr. George Ndi for helpful comments and also thanks to two anonymous referees for their comments on earlier drafts.

\section{References}

Acharya, S., and Mohan, R. (eds.) (2010) Indian Economic Performance and Challenges. New Delhi: Oxford University Press

Acharya, S. (2004). India's Growth Prospects Revisited. Economic and Political Weekly, Vol.39 (41), p. 4537-42, Mumbai.

Ahluwalia, M. S. (2002). Economic Reforms in India since 1991: Has Gradualism Worked?. Journal of Economic Perspective, Vol. 16, No.7, pp.67-68

Ahmed, V., and Amjad, R. (1984). The Management of Pakistan's Economy, 1947-82, p.77, Karachi: Oxford University Press

Alavi, Hamza. (1998). “Pakistan-US Military Alliances”, in Economic and Political Weekly, vol. 33, No.25, June: Mumbai.

Alavi, Hamza (Ed.). (1983). Class and State in Pakistan: The Roots of Dictatorship. London: Zed Books.

Ali, Tariq. (2008). The Duel- Pakistan on the Flight Path of American Power. London: Simon and Schuster, page 256.

Amjad, R. (1982). Private Industrial Investment in Pakistan, 1960-70. Cambridge: Cambridge University Press.

Amsden, A.H. (1989). Asia’s Next Giant: South Korea and Late Industrialisation. New York: Oxford University Press.

Anwar, T. (1996). Structural Adjustment and Poverty: The Case of Pakistan. The Pakistan Development Review, Vol.35, No.4, winter issue, pp.911-924.

Asian Development Bank. (2008). Key Indicators, Manila. [Online] Available: http://www.adb.org (10 ${ }^{\text {th }}$ June 2010).

Asian Development Bank. (2001). Pakistan: Country Operational Strategy, Manila [Online] Available: http://www.adb.org. (3 ${ }^{\text {rd }}$ October 2010).

Asian Development Bank (1985). Strategies for Economic Growth and Development: The Bank’s Role in Pakistan, Manila.

Bagchi, A.K. (1976). De-industrialization in Indian in the Nineteenth Century. Journal of Development Studies, January. 


\section{Macrothink}

Research in Applied Economics

ISSN 1948-5433

2011, Vol. 3, No. 1: E1

Basu, S., and Mallick, S. (2008). When Does Growth Trickle Down to the Poor? The Indian Case. Cambridge Journal of Economics, Vol. 32, pp461-477), Mumbai. .

Byres, Terry. (1994). The State and Development”, in Terry Byres, Terry (Edi.) The State and Development Planning in India, Oxford University Press

Chang, H.-J. (1994). The Political Economy of Industrial Policy. London: Macmillan.

Chatterjee, S. (2008). The Anatomy of Recent Transformation of the Economies of China and India, Discussion Paper, Palmerston North: Massey University, Dept. of Economics.

Dasgupta, S., and Singh, Ajit. (2005). Will Services be the New Engine of Indian Economic Growth?. Development and Change, Vol. 36, Issue 6, Blackwell Publishers

Deaton, Angus. (2003). Prices and Poverty in India, 1987-2000. Economic and Political Weekly, pp.362-368, January 25, Mumbai.

Dev, M.S., and Ravi, C. (2007). Poverty and Inequality: All Indian and States, 1983-2005. Economic and Political Weekly, Vol. 42, No.6, pp 509 - 21, Mumbai

Dreze, J., and Sen, A.K. (2002). India: Development and Participation. Oxford University Press, New Delhi.

Easterly, W. (2001). The Political Economy of Growth without Development: A Case Study of Pakistan. Development Research Group, Washington D.C.: The World Bank.

Economic Surveys. (2000-09). Various issues, Ministry of Finance. New Delhi: Government of India.

Economic and Political Weekly. (2010). Editorial section, September 15th, P.7: Mumbai.

Economic and Political Weekly Research Foundation, 2004, Domestic Products of States of India, 1960-61 to 2000-01, Mumbai.

Felipe, J., and Lim, J. (2008). An Analysis of Pakistan's Macroeconomic Situation and Prospects, Working Paper N. 136, Manila: Asian Development Bank.

Frankel, Francine R. (1978). India's Political Economy-1977 - the Gradual Revolution. Princeton: Princeton University Press.

Gardezi, Hassan N. (1998). The Failure of Capitalism in Pakistan. Journal of Contemporary Asia, Vol. 28, No. 3, pp. 310-326.

Gardezi, Hassan N. (1991). Understanding Pakistan: The Colonial Factor in Societal Development. Lahore: Maktaba Publishers.

Ghosh, Jayati (2004). "Imperialist Globalisation and the Political Economy of South Asia”, in Freeman, Alan and Kagarlitsky, Boris (Eds) (2004) The Politics of Empire, London: Pluto Press.

Girdner, Eddie, J, and Siddiqui, Kalim. (2008). Neo-liberal Globalization, Poverty Creation and Environmental Degradation in Developing Countries. International Journal of 
Environment and Development, Vol. 5, No.1, January-June, pp 1-27

Habib, Irfan. (1995). "Colonisation of the India Economy”, in Essays in Indian History: Towards a Marxist Perception, New Delhi: Tulika Publishers.

Harriss-White, Barbara. (2003). India Working: Essays on Society and Economy. Cambridge: Cambridge University Press.

Harvey, David. (2005). A Brief History of Neo-liberalism. Oxford University Press: London

Hasan, Parvez. (1998). Pakistan's Economy at the Crossroads: Past Policies and Present Imperatives. Karachi: Oxford University Press.

Hussain, A. (1988). "Land Reforms in Pakistan”, in Hussain, A. (edi) Strategic Issues in Pakistan’s Economic Policy, p. 178, Lahore: Progress Publishers.

Institute of Developing Economics. (1994). Tokyo, p. 324

International Food Policy Research Institute (IFPRI). (2008). India State Hunger Index.

Jalal, Ayesha. (1995). Democracy and Authoritarian in South Asia. Cambridge: Cambridge University Press.

Jalal, Ayesha. (1990). The State of the Martial Rule: The Origins of Pakistan's Political Economy of Defence. Cambridge: Cambridge University Press.

Jayadev, A., Motiram, S., and Vakulabharanam, V. (2007). Patterns of Wealth Disparities in India during the Liberalisation Era. Economic and Political Weekly, pp.3853-3863, September 22, Mumbai.

Kalecki, Michael. (1976). Essays on Developing Economies. London: Harvester Press.

Khan, S.R. (2007). Pakistan's Economy Since 1999: Has There Been Any Real Progress?. South Asian Journal, Vol.8, No.2, pp.317-34.

Khanna, S. (2010). Growth and Crisis in Pakistan Economy. Economic and Political Weekly, December 20, pp.39-46, Mumbai.

Kibria, Gulam. (1999). A Shattered Dream: Understanding Pakistan's Underdevelopment. Karachi: Oxford University Press.

Kochhar, K., Kumar, U., Rajan, R., Subramanian and Tokatlidis, I. (2006). India's Pattern of Development: What Happened, What Follows, IMF Working Paper No. 06/22, Washington D.C.

Mukherjee, Aditya. (2010). Empire: How Colonial India Made Modern Britain. Economic and Political Weekly, December 11, Vol. XLV, No.50, pp.73-82.

Nagaraj, R. (2006). Public Sector Performance Since 1950: A Fresh Look. Economic and Political Weekly, 41 (25) pp.2551-57.

Noman, Omar. (1997). Economic and Social Progress in Asia: Why Pakistan Did Not Become 
A Tiger. Karachi: Oxford University Press.

Pakistan Economic Survey. (1996). Government of Pakistan, Ministry of Finance. Islamabad: Printing Corporation of Pakistan.

Patnaik, Utsa. (2010). “On Some Fatal Fallacies”, in Economic and Political Weekly, Vol. xiv, No.47, page 82, November $20^{\text {th }}$, Mumbai.

Patnaik, Prabhat. (2010). The Diffusion of Activities. Economic and Political Weekly, Vol. xiv, Number 10, Mumbai.

Patnaik, Prabhat. (2007). A Model of Growth for the Contemporary India Economy. Economic and Political Weekly, June 2nd, Mumbai

Patnaik, Prabhat. (1994). International Capital and National Economic Policy: A Critique of India's Reforms”, Economic and Political Weekly, Vol. 20, Number 12, p. 684, Mumbai.

Prebisch, Raul (1961). Joint Responsibilities for Latin American Progress. Foreign Affairs, Vol.39, issue, 4, New York.

Rangarajan, C. (1982). Agriculture Growth and Industrial Performance in India. Washington D.C.: International Food Policy Research Institute.

Reserve Bank of India. (2008). Handbook of Statistics on Indian Economy, Government of India. Also 2009.

Rodrik, D., and Subramanian, A. (2004).Why India can Grow at Seven Percent a Year or More: Projections and Reflections. Economic and Political Weekly, 39 (16)

Rodrik, D. (2003). Growth Strategy. Working Paper, September, Harvard University.

Sachs, Goldman. (2007). BRICs and Beyond. [Online] Available: http://www.goldmansachs.com/ideas/brics-and-beyond.html, accessed on 14.10.2010

Sarkar, S., and Mehta, B.S. (2010). Income Inequality in India: Pre and Post Reform Period. Economic and Political Weekly, Vol. xiv, No.37, September 11th, Mumbai.

Siddiqui, Kalim. (2010a). The Political Economy of Development in Singapore. Research in Applied Economics, Vol.2, No.2, [Online] Available: http://ww.macrothink.org/rae

Siddiqui, Kalim (2010b) "Globalisation and Neo-liberal Economic Reforms in India: A Critical Review”, in (Eds.) by S. K. Pramanick and R. Ganguly, Globalization in India: New Frontiers and Emerging Challenges, (pp 219-243) New Delhi: Prentice Hall of India, ISBN-978-81-203-4038-1

Siddiqui, Kalim. (2009a). The Political Economy of Growth in China and India. Journal of Asian Public Policy (JAPP), March, Vol.1, No.2, pp.17-35

Siddiqui, Kalim (2009b). Japan’s Economic Crisis. Research in Applied Economics”, Vol. 1, No. 2, 2009, pp 1-25. [Online] Available: http://ww.macrothink.org/rae

Siddiqui, Kalim. (2008). “Globalisation and Developing Countries: Opportunities or 


\section{Al Macrothink}

Research in Applied Economics

ISSN 1948-5433

2011, Vol. 3, No. 1: E1

Marginalisation?”, in Verma, S. B. et al (Eds.) Globalisation at the Cross Roads, New Delhi: Sarup \& Sons Publishers, India, (pp.46-71)

Siddiqui, Kalim. (1999a). “New Technology and Process of Differentiation: Two Sugarcane Cultivating Villages in UP, India”, Economic and Political Weekly, 25th December, 1999, No. 52, vol. xxxiv (pp A39-A53), Mumbai, India.

Siddiqui, Kalim. (1999b). "Credit and Marketing of Sugarcane: A field study of two villages in Western Utter Pradesh”, Social Scientist, Vol.25, Numbers 1-2, (pp 62-93) January, New Delhi

Siddiqui, Kalim. (1998). “The Export of Agricultural Commodities, Poverty and Ecological Crisis: A Case Study of Central American Countries”, Economic and Political Weekly, Sept. 26, 1998, vol. xxxiii, No. 39, pages A128-A137

Siddiqui, Kalim. (1996). "Growth of Modern Industries under Colonial Regime: Industrial Development in British India between 1900 and 1946”, Pakistan Journal of History and Culture, xvii/1, (pp 11-59) January.

Siddiqui, Kalim. (1990). "Historical Roots of Mass Poverty in India” in C.A. Thayer et al. (Eds.) Trends and Strains, People’s Publishing House, New Delhi, (pp 59-76)

Siddiqui, Kalim. (1989). “Militarization of Pakistan’s Economy and Politics”, Klassekampen, (in Norwegian) part i, 3rd August and part ii, 4th August, Oslo, Norway

Sundaram, K., and Tendulkar, S.D. (2003). Poverty in India in the 1990s: An Analysis of Changes in 15 Major States. Economic and Political Weekly, pp. 1385-1393, April 5, Mumbai.

Tendulkar, S., and Jain, L.R. (1995). Economic Reforms and Poverty. Economic and Political Weekly, vol. xxx, pages $1373-77$.

The Economist. (2010). India’s Surprising Economic Miracle. October 2nd, p.11, London.

UNCTAD. (1996). Trade and Development Report. New York: United Nations.

UNDP. (2007). Human Development Report. United Nations: New York.

UNIDO. (1990). Pakistan: Towards Industrial Liberalisation and Revitalisation. Oxford: Blackwell Publishers.

Vakulabharanam, V. (2010). Does Class Matter? Class Structure and Worsening Inequality in India. Economic and Political Weekly, July 17th, vol. xiv, No. 29, pages 67-76, Mumbai.

World Bank. (2010). World Development Indicators. Washington D.C.: World Bank

World Bank. (2006). Pakistan: Growth and Export Competitiveness. Report No.35499-PK, Washington D.C.

World Bank. (2003). Global Economic Prospects and the Developing Countries: Washington DC. 
World Bank. (1997). India: Achievements and Challenges in Reducing Poverty, A World Bank Country Study, (pp xiii-xvi): Washington DC.

Zaidi, S. Akbar. (2005). Issues in Pakistan's Economy, second edition, Karachi: Oxford University Press.

Zaidi, S. Akbar. (1999). Is Poverty now a Permanent Phenomenon in Pakistan?. Economic and Political Weekly, 34 (4), October 9, Mumbai.

\section{Notes}

Note 1. Import-substitution industrialisation (ISI) an economic strategy aimed at encouraging national industrial growth so as to reduce imports of manufactured goods. An economic theory employed by developing nations that wish to increase their self-sufficiency and decrease their dependency on developed countries. Implementation of the theory focuses on protection and incubation of domestic infant industries so they may emerge to compete with imported goods and make the local economy more self-sufficient. It was associated with the United Nations Commission for Latin America and put into practice during the 1960s (H.-J. Chang, 1994; Raul Prebisch, 1961)

Note 2. Export-led growth also known as export-oriented industrialisation (EOI) is a term used loosely to refer to a strategy comprising the encouragement of and support for production for exports. Such policies are regarded as crucial growth stimulators. It is said to be an efficient means of introducing new technologies, both to the exporting firms in particular and to the rest of the economy, and exports are a channel for learning and technological advancement. It was the export promotion strategy that accounted for East Asian's states' success of economic development during the 1980s. This strategy was fully supported by the International financial institutions such as IMF and the World Bank. (The Economist, 2010; Harvey, 2005; Acharya, 2004; World Bank, 1997)

Note 3. See Irfan Habib (1995) "Colonisation of the India Economy", in Essays in Indian History: Towards a Marxist Perception, New Delhi: Tulika Publishers.

Note 4. The term of 'Hindu rate of growth' was coined by Raj Krishna to describe the relatively low rate of GDP growth of the Indian economy in the period of 1950-80, when average growth was around $3 \%$ per annum.

Note 5. With the adoption of the neo-liberal economic (i.e. pro-market) reforms in 1991, much of industrial licensing system was dismantled and many areas once closed to private sector were opened as electricity industry, air lines, oil, steel, telecommunications etc. The top income tax rate was also reduced and corporate tax fell from 57.5 to $46 \%$ in 1991 and further to $35 \%$ in 1997. The government also undertook the decision to privatised government owned industries.

Note 6. East Asian countries did not adopt greater outward orientation, as proclaimed by mainstream economists. In fact, only Hong Kong and Singapore have adopted free trade 
policies, with virtually no tariff barriers. To varying degrees other East Asian countries adopted interventionist but also pro-market policies, involving some use of export promotion, selective import barriers and industrial policies.

Note 7. See for instance, S. Acharya and R. Mohan (Eds.) (2010) Indian Economic Performance and Challenges, New Delhi: Oxford University Press; also S. Acharya (2004) 'India’s Growth Prospects Revisited', Economic and Political Weekly, Vol.39 (41), p. 4537-42, Mumbai; Ahluwalia (2002).

Note 8. For detail explanation on this, see Dave Harvey’s book on Neo-liberalism, (2005).

Note 9. Figures from "Indian IT industry fact sheet", available at http://www.nasscom.in/upload/5216/indian-IT-indusrty-factsheet-2006.doc

Note 10. Prabhat Patnaik (2007) argues that the stagnation crisis is due to over consumption, which is mitigated by investment demand fuelled by elite consumption of new products.

Note 11. National Sample Survey (NSS) is conducted by the Planning Commission, Government of India.

Note 12. These issues have been raised regarding the correspondence between official poverty lines calorie-based nutritional needs and the large differences in the value of consumption expenditures.

Note 13. For the detailed discussions on experiences of export-led growth in Central America, see Kalim Siddiqui, (1998).

Note 14. For more detail see Hamza Alavi (1998) "Pakistan-US Military Alliances”, in Economic and Political Weekly, vol. 33, No.25, June.

Note 15. The ruling elites in Pakistan consist of the large landowners, the civil bureaucracies, and the military.

Note 16. However, during the 1980s and 1990s the developing countries of sub-Saharan Africa and Latin America under enormous external pressure carried out 'neo-liberal' economic reforms. The result was a decline in living conditions for the majority of the population. During the post-reform period, the income and wealth of the rich increased, while the incomes poor witnessed dramatic fall. These countries were growing much faster in the pre-reform periods i.e. 1960s and 1970s when their economies were not liberalised.

Note 17. See UNCTAD (1996) Trade and Development Report discusses on the role of the dynamic export-investment nexus in explaining East Asian miracle. Also see A.H. Amsden (1989).

Note 18. For a village level study in India see Kalim Siddiqui (1999) “New Technology and Process of Differentiation: Two Sugarcane Cultivating Villages in UP, India”, Economic and Political Weekly, 25th December, 1999, No. 52, vol. xxxiv (pp A39-A53), Mumbai, India.

Note 19. I mean to say with the implementation of land reforms and involvement of middle and poor farmers, the agricultural outputs and incomes of these rural groups would have 


\section{Macrothink}

Research in Applied Economics

ISSN 1948-5433

2011, Vol. 3, No. 1: E1

increased. Thus, it would have created extra demands for domestic industrial products. For example, Germany in the late $19^{\text {th }}$ century and South Korea and Taiwan in the late $20^{\text {th }}$ century support this point.

Note 20. 'Green Revolution' technologies are another product of government intervention. This was carried out through subsidisation of inputs - new seeds, chemical fertilizers, credits and irrigation.

Note 21. In Pakistan the public revenue declined as a percentage of GDP as custom duties revenue fell from 5.9 to $4.9 \%$ of the GDP. For more detail see T. Anwar (1996).

\section{Copyright Disclaimer}

Copyright reserved by the author(s).

This article is an open-access article distributed under the terms and conditions of the Creative Commons Attribution license (http://creativecommons.org/licenses/by/3.0/). 